\title{
7-O-Methylpunctatin, a Novel Homoisoflavonoid, Inhibits Phenotypic Switch of Human Arteriolar Smooth Muscle Cells
}

\author{
Manal Fardoun ${ }^{1}$, Rabah Iratni ${ }^{2}$, Hassan Dehaini ${ }^{3}$, Assaad Eid ${ }^{4}$, Tarek Ghaddar ${ }^{5}$, \\ Tamam El-Elimat ${ }^{6}(\mathbb{D})$, Feras Alali ${ }^{7}\left(\mathbb{D}\right.$, Adnan Badran ${ }^{8}$, Ali H. Eid ${ }^{3,9, *}$ and Elias Baydoun ${ }^{1, *}$ \\ 1 Department of Biology, Faculty of Arts and Sciences, American University of Beirut, P.O. Box 11-0236, Beirut, \\ Lebanon;mmf27@mail.aub.edu \\ 2 Department of Biology, College of Science, United Arab Emirates University, P.O. Box 15551, Al-Ain, UAE; \\ r_iratni@uaeu.ac.ae \\ 3 Department of Pharmacology and Toxicology, Faculty of Medicine, American University of Beirut, \\ P.O. Box 11-0236, Beirut, Lebanon; had29@mail.aub.edu \\ 4 Department of Anatomy, Cell Biology and Physiological Sciences, Faculty of Medicine, \\ American University of Beirut, P.O. Box 11-0236, Beirut, Lebanon; ae49@aub.edu.lb \\ 5 Department of Chemistry, Faculty of Arts and Sciences, American University of Beirut, P.O. Box 11-0236, \\ Beirut, Lebanon; tg02@aub.edu.lb \\ 6 Department of Medicinal Chemistry and Pharmacognosy, Faculty of Pharmacy, Jordan University of Science \\ and Technology, P.O. Box 3030, Irbid 22110, Jordan; telimat@just.edu.jo \\ College of Pharmacy, Qatar University, Doha P.O. Box 2713, Qatar; feras.alali@qu.edu.qa \\ 8 Department of Nutrition, University of Petra, Amman, P.O. Box 961343, Amman 11196, Jordan; \\ abadran@uop.edu.jo \\ 9 Department of Biomedical Sciences, College of Health Sciences, Qatar University, Doha P.O. Box 2713, Qatar \\ * Correspondence: ae81@aub.edu.lb (A.H.E.); eliasbay@aub.edu.lb (E.B.); Tel.: +961-1-35000 (ext. 4891) (A.H.E.)
}

Received: 6 August 2019; Accepted: 9 October 2019; Published: 8 November 2019

\begin{abstract}
Remodeling of arterioles is a pivotal event in the manifestation of many inflammation-based cardio-vasculopathologies, such as hypertension. During these remodeling events, vascular smooth muscle cells (VSMCs) switch from a contractile to a synthetic phenotype. The latter is characterized by increased proliferation, migration, and invasion. Compounds with anti-inflammatory actions have been successful in attenuating this phenotypic switch. While the vast majority of studies investigating phenotypic modulation were undertaken in VSMCs isolated from large vessels, little is known about the effect of such compounds on phenotypic switch in VSMCs of microvessels (microVSMCs). We have recently characterized a novel homoisoflavonoid that we called 7-O-methylpunctatin (MP). In this study, we show that MP decreased FBS-induced cell proliferation, migration, invasion, and adhesion. MP also attenuated adhesion of THP-1 monocytes to microVSMCs, abolished FBS-induced expression of MMP-2, MMP-9, and NF-KB, as well as reduced activation of ERK1/2 and FAK. Furthermore, MP-treated VSMCs showed an increase in early (myocardin, SM-22 $\alpha, \mathrm{SM}-\alpha$ ) and mid-term (calponin and caldesmon) differentiation markers and a decrease in osteopontin, a protein highly expressed in synthetic VSMCs. MP also reduced transcription of cyclin D1, CDK4 but increased protein levels of p21 and p27. Taken together, these results corroborate an anti-inflammatory action of MP on human microVSMCs. Therefore, by inhibiting the synthetic phenotype of microVSMCs, MP may be a promising modulator for inflammation-induced arteriolar pathophysiology.
\end{abstract}

Keywords: vascular smooth muscle cells; inflammation; phenotypic switch; homoisoflavonoids; 7-O-methylpunctatin; arterioles 


\section{Introduction}

Arterioles are internally wrapped with one or more layers of vascular smooth muscle cells (VSMCs) [1]. Under normal physiological conditions, VSMCs assume a contractile phenotype [2]. It is this phenotype that is largely responsible for the contractility of blood vessels, allowing them to tightly control vasotone and regulate flow both under physiologic and pathophysiologic conditions [2-4]. In response to inflammatory cues, VSMCs switch from the contractile to a dedifferentiated synthetic phenotype, with increased proliferative and migratory abilities [2]. This VSMC phenotypic switch plays a key role in vascular/arteriolar inflammation and remodeling [5].

The use of herbal medicine in the prevention and treatment of cardiovascular disease (CVD) has been substantially growing [6,7]. Remarkably, the PubMed database contains more than 600 clinical trials and around 3300 publications dealing with herbal drugs for CVDs [7]. These reports provide scientific evidence on the beneficial role of herbal medicine in CVD. Among the many herbal compounds associated with cardio-vasculoprotective effects are flavonoids [8-12]. For instance, the flavonoid-rich herb Scutellaria baicalensis was reported to confer protection against ischemic heart disease [13]. Likewise, flavonoids are known to ameliorate atherosclerosis [14] and exert an antihypertensive effect [15]. Importantly, several studies tested the effect of many chemicals/flavonoids with anti-inflammatory actions on vascular cells. Nonetheless, most of these drugs were tested on VSMCs isolated from large vessels [16-19]. Indeed, very little is known about compounds targeting arteriolar inflammation.

A special class of flavonoids distinguished by one additional carbon atom on their carbon cytoskeleton are the homoisoflavonoids (3-benzylidenechroman-4-ones) [20]. They constitute a rare class of natural compounds [20]. More than 240 natural homoisoflavonoids have so far been reported, all restricted to only six plant families: Fabaceae, Asparagaceae, Polygonaceae, Portulacaceae, Orchidaceae, and Gentianaceae $[16,20,21]$. Recently, homoisoflavonoids have been receiving increased interest due to their broad spectrum of biological effects [20]. These include anti-inflammatory [22], anti-hyperglycemic [23], anti-mutagenic [24], anti-microbial [25], antiviral [26], and anti-oxidant activities [27]. The anti-oxidant effect seems to be the most important and most extensively studied owing to its potentially beneficial effects in diabetes and inflammation [28] and CVD [29]. For instance, Ophiopogonin japonicus, rich in anti-oxidative homoisoflavonoids, appears to be effective in treating myocardial ischemia and arrhythmias [29]. Thus, by virtue of their anti-oxidative potential, homoisoflavonoid-rich plants may be regarded as an important resource in the management or treatment of CVD.

Bellevalia eigii Feinbrun is a perennial plant belonging to the family Asparagaceae [16,30]. It is native to Mediterranean region and Sinai [31] and is widespread in Jordan, where it is known among local people as "the Jordan Valley onion" [16]. From the bulbs of Bellevalia eigii Feinbrun, we recently isolated, purified and characterized a new compound, 7-O-methylpunctatin (MP) [16] (Figure 1). Here, we sought to determine the effect MP on fetal bovine serum (FBS)-induced inflammation of human VSMCs extracted from dermal arterioles.

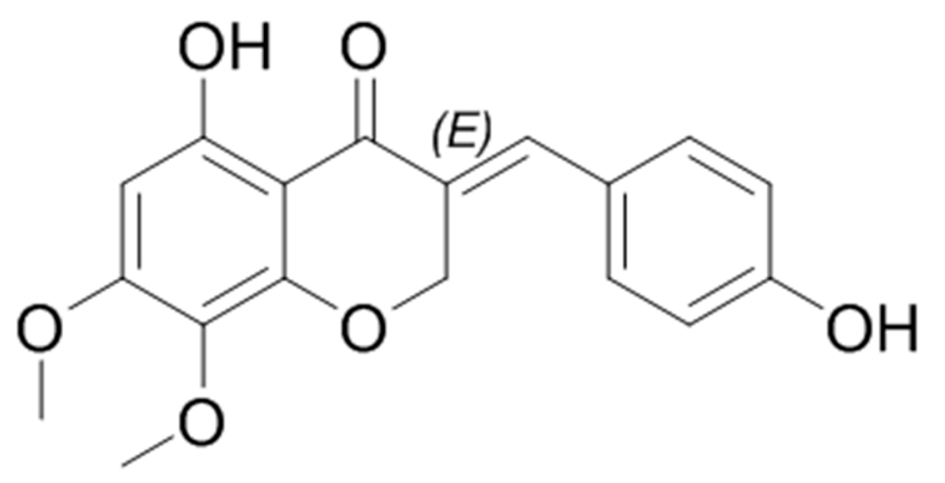

Figure 1. The chemical structure of 7-O-methylpunctatin (MP). 


\section{Materials and Methods}

\subsection{Reagents}

Anti-Calponin antibody (ab46794), anti-Caldesmon antibody (ab32330), anti- $\beta$ actin antibody (ab119716), anti-ERK1/2 antibody (ab17942), anti-ERK1 (phospho Y204) + ERK2 (phospho Y187) antibody (ab47339), anti-FAK antibody (ab61113), anti-FAK antibody (phospho Y397, ab81298), HRP-conjugated Goat Anti-Mouse antibody (ab97040), HRP-conjugated Goat Anti-Rabbit antibody (ab ab150080), and Tetrazolium (ab146345) were purchased from Abcam (Cambridge, UK). Anti-GAPDH

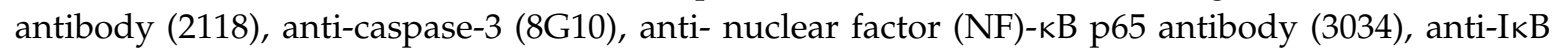
antibody (9242), and anti-IкB $\alpha$ (phospho Ser32/36, 9246) were obtained from Cell Signaling Technology (Leiden, The Netherlands). Anti-p21antibody (sc-397) and anti-p27 antibody (sc-1641) were purchased from Santa Cruz Biotechnology (Dallas, TX, USA). Dulbecco's Modified Eagle's Medium/Nutrient Mixture F-12 Ham DMEM: F12 (BE12-719F), RPMI-1640, Penicillin/Streptomycin (17-602E), and Trypsin (BE02-007E), DMSO (0231) were obtained from Lonza (Basel, Switzerland). Fetal Bovine Serum FBS (F9665), Phosphorous Buffer Saline PBS (D1408), and Propidium Iodide (P4170) were purchased from Sigma-Aldrich (Schnelldorf, Germany). MMP-2 and MMP-9 ELISA kits were obtained from R\&D Systems (Minneapolis, MN, USA), DC Protein Assay kit and ClarityWestern ECL Substrate from Bio-rad (Irvine, CA, USA), BrdU kit from Roche Diagnostics (Penzberg, Germany), Luciferase Assay Kit from Promega (Fitchburg, WI, USA), Moloney murine leukemia virus reverse transcriptase (RT) from Invitrogen (Carlsbad, CA, USA), and SYBR Green fluorophore from SuperArray Bioscience Corporation (Frederick, MD, USA).

\subsection{Cell Culture}

Human arteriolar smooth muscle cells were extracted by the non-enzymatic sprouting method from post-circumcision tissue of a newborn boy. No IRB approval is needed as this source is considered clinical waste. Cells were grown in Ham's Growth medium (DMEM: F12, 50:50; supplemented with $10 \%$ FBS, and 1\% penicillin/streptomycin). Only cells of passages 8-11 were used. Before treatment, cells were synchronized by starvation in a quiescent serum-free medium (DMEM: F12, 50:50, 0.5\% FBS, 1\% penicillin/streptomycin) for $48 \mathrm{~h}$, as previously described [32]. THP-1 cells were cultured in RPMI-1640 and supplemented with 10\% FBS and 1\% penicillin/streptomycin. Cells were maintained in a humidified incubator at $37{ }^{\circ} \mathrm{C}$ with $5 \% \mathrm{CO}_{2}$ atmosphere.

\subsection{Preparation of 7-O-methylpunctatin}

Extraction, characterization, and purification of MP was done as we recently reported [16]. MP was stored at $-20^{\circ} \mathrm{C}$, and for cell treatment, it was dissolved in DMSO. The dissolved compound was stored in the dark at $-20^{\circ} \mathrm{C}$.

\subsection{MTT Assay}

VSMCs were grown in 96-well plate until they reached $30-40 \%$ confluence. Then cells were starved in serum-free medium for $48 \mathrm{hrs}$. Following starvation, cells were treated with increasing concentrations of MP for 24, 48, and $72 \mathrm{~h}$. MTT solution $(20 \mu \mathrm{L}, 5 \mathrm{mg} / \mathrm{mL})$ was added to each well, and cells were incubated for an hour in a $5 \% \mathrm{CO}_{2}$ incubator. The medium was then removed, and $200 \mu \mathrm{L}$ DMSO was added to each well. The plate was placed on a shaker for 15 min to allow for the dissolution of formazan crystals. Using an ELISA Multiscan EX Reader (Thermo Fisher, Vantaa, Finland), optical density was read at $550 \mathrm{~nm}$. Absorbance is directly proportional to cell viability.

\subsection{BrdU Incorporation Assay}

Here, five thousand cells/well were seeded into 96-well plates. Cells were then starved for $48 \mathrm{~h}$ before commencing any treatment. Cell proliferation was then measured with BrdU kit (Roche Diagnostics, 
Penzberg, Germany) following the manufacturer's protocol. Optical density was measured using a microplate reader spectrophotometer at excitation wavelength $450 \mathrm{~nm}$.

\subsection{Cell Cycle Analysis}

Cells were made quiescent by culturing in starvation medium for $48 \mathrm{~h}$. After starvation, cells were treated for $48 \mathrm{~h}$ with complete medium in the absence or presence of MP. They were then washed with PBS, trypsinized, and collected by centrifugation. After washing twice with ice-cold PBS, cells were re-suspended in $500 \mu \mathrm{L}$ PBS. For permeabilization and fixation, $2 \mathrm{~mL}$ of ice-cold pure ethanol was added for $15 \mathrm{~min}$. The cell suspension was centrifuged, and the cell pellet was washed twice with PBS. Cells were then incubated for $10 \mathrm{~min}$ in $1 \mathrm{mg} / \mathrm{mL}$ of propidium iodide in PBS. Propidium iodide (PI) fluorescence was read using Guava EasyCyte8 Flow Cytometer (Luminex, Hayward, CA, USA). Cell cycle analysis was done using Guava Soft 2.7 software.

\subsection{RT-PCR}

Cells were seeded and allowed to grow in complete medium, then starved for $48 \mathrm{~h}$. Total RNA was extracted using Nucleospin RNA II kit as per the manufacturer's protocols (Machery Nagel, Germany). cDNA was then synthesized using $1 \mu \mathrm{g}$ of total RNA by RevertAid 1st strand cDNA synthesis kit (Thermo Fisher ScientificF). RT-PCR was then performed using the iQ SYBR green supermix. Using serial dilutions of cDNA of positive controls for each gene of interest, standard curves are determined and plotted, and then the threshold cycle value $(\mathrm{Ct})$ obtained for each gene and normalized to the housekeeping gene GAPDH (internal control). The $\Delta \Delta \mathrm{Ct}$ method was used to analyze expression changes between the different conditions, where the control untreated group value is set to one. Gene sequences were amplified using the following primers:

- Cyclin D1F: TCCTGTGCTGCGAAGTGGAAAC;

- Cyclin D1R: AAATCGTGCGGGGTCATTGC;

- cdk4F: AAGAGTGTGAGAGTCCCCAATGG;

- $\quad$ cdk4R: GATTTTGCCCAACTGGTCGG;

- Myocardin F: GAGAGGTCCATTCCAACTGC;

- Myocardin R: GGGCTGTGAGGCTGAGTC;

- SM-22 $\alpha$ F: TCCAGGTCTGGCTGAAGAATGG;

- SM-22 $\alpha$ R: CTGCTCCATCTGCTTGAAGACC;

- SM- $\alpha$ F: ACTGAGCGTGGCTATTCCTCCGTT

- SM- $\alpha$ R: GCAGTGGCCATCTCATTTTCA;

- GAPDH F: CGCTCTCTGCTCCTCCTGTTC;

- GAPDH R: TTGACTCCGACCTTCACCTTCC.

\subsection{Phase Contrast Microscopy}

VSMCs were grown in 6-well plates. Cells were then starved for $48 \mathrm{~h}$ then treated with complete medium in the absence or presence of MP. Images were acquired using a phase-contrast microscope (Zeiss, Oberkochen, Germany) after 24, 48, and $72 \mathrm{~h}$.

\subsection{Scanning Electron Microscopy}

Cells were cultured in complete medium on coverslips in 12-well plates. At $80 \%$ confluency, cells were starved for $48 \mathrm{~h}$, then treated with complete medium in the absence or presence MP for $48 \mathrm{hrs}$. Wells were then washed and cells fixed with $2.5 \%$ glutaraldehyde for $45 \mathrm{~min}$ at $4{ }^{\circ} \mathrm{C}$. After washing with PBS, cells were dehydrated with increasing ethanol concentrations $(25,50,75,95$, and $100 \%)$ for $5 \mathrm{~min}$ per incubation. The coverslips were mounted on scanning electronic miscoscope (SEM) stub, cells were sputtered with gold and images were acquired using Tescan SEM (MIRA3 software; Brno; Czech Republic). 


\subsection{Wound Healing (Scratch) assay}

Cells were cultured in 12-well plates until $90-95 \%$ confluent. They were then incubated in quiescent medium $(0.5 \%$ FBS) for $48 \mathrm{~h}$. Using a $10 \mu \mathrm{L}$ sterile pipette tip, a scratch was made on the cellular monolayer. Wells were washed with PBS to remove cellular debris, and medium was replenished in the absence or presence of MP. Wound healing was monitored at $0,2,4,6,8,12$, and $24 \mathrm{~h}$, and photomicrographs were taken using a Zeiss phase contrast microscope. ZEN imaging software (blue edition) from Zeiss was used to measure the width of the scratch.

\subsection{Invasion Assay}

Transwell inserts were coated with matrigel and allowed to dry overnight under ultraviolet light. Cells in serum-free media were seeded onto the rehydrated upper transwell chamber in the absence or presence of MP. The lower chamber was loaded with complete medium, acting as a chemotactic attractant. Cells were then incubated at $37^{\circ} \mathrm{C}$ for $24 \mathrm{~h}$. After treatment, the medium was aspired, and wells were washed with PBS. Non-invading cells were removed from the upper surface with a cotton swab, whereas invading cells were fixed with methanol and stained with DAPI. The membrane was cut with a blade and mounted on an anti-fade agent. Slides were observed under Zeiss Axio fluorescent microscope. Cells from at least five different fields were counted.

\subsection{Cell Adhesion Assay}

Cells in starvation medium were seeded in 6-well plates and allowed to adhere for $1 \mathrm{~h}$ at $37^{\circ} \mathrm{C}$. Then, wells were gently washed with PBS to remove non-adherent cells. Images were acquired using Zeiss phase contrast microscope and adherent cells were counted.

\subsection{Monocyte Adhesion Assay}

Cells were grown in complete medium until confluence. Cells were then treated with MP for 1hour followed by treatment with phorbol myristate acetate (PMA) for $20 \mathrm{~h}$. THP-1 cells labelled with NucBlue (Thermo Fischer Scientific) were added over the VSMC monolayer and allowed to adhere for $30 \mathrm{~min}$. Non-adherent THP-1 cells were removed by washing the wells with PBS. Images of the adherent THP-1 cells were acquired using Zeiss Axio fluorescent microscope. In addition, quantitative analysis was done by measuring the fluorescence intensity of five random fields of photomicrographs.

\subsection{Measurement of MMP-2 and MMP-9}

Cells were grown to a subconfluent level and then starved for $48 \mathrm{~h}$. Following treatment with the respective conditions, medium of each condition was collected for MMP-2 and MMP-9 detection using ELISA kits (R\&D Systems), as recommended by the manufacturer and we recently reported [33].

\subsection{Actin Staining}

At $30-40 \%$ confluence, cells were starved in quiescent medium for $48 \mathrm{~h}$. Following treatment, cells were washed twice with PBS, fixed with $4 \%$ paraformaldehyde, and permeabilized with $0.1 \%$ Triton $\mathrm{X}-100$. Cells were then washed again and incubated with Rhodamine phalloidin stain for $1 \mathrm{~h}$ in the dark. Cells were washed again, and nuclei were counter-stained with DAPI for $15 \mathrm{~min}$ at room temperature. Cells were mounted on an anti-fading agent and visualized using Zeiss Axio fluorescent microscope.

\subsection{Luciferase Reporter Assay}

As we previously reported [34], cells were transiently transfected with NF- $\mathrm{KB}$-driven promoter luciferase using Amaxa Nucleofector (Amaxa Biosystems, Gaithersburg, MD, USA) according to the manufacturer's protocol. Renilla luciferase vector was used as an internal control, to which firefly luciferase values were normalized. Following transfection, cells were allowed to recover overnight, 
and then starved for $48 \mathrm{~h}$. After treatment, cells were washed and lysed in luciferase lysis buffer (Promega), and luciferase activity was measured.

\subsection{Western Blotting}

Cells were washed with PBS and then lysed using 2\% SDS, $60 \mathrm{mM}$ Tris lysis buffer ( $\mathrm{pH}$ 6.8) as previously described [35]. Proteins were quantified using DC Protein Assay and equal amounts of protein $(20-30 \mu \mathrm{g})$ were loaded and separated using 5-11\% SDS-PAGE. Proteins were then transferred onto polyvinylidene difluoride (PVDF) membrane (Biorad). After blocking in 5\% fat-free milk in TBS-T, $1 \mathrm{~h}$ at room temperature, the membrane was incubated overnight with the relevant primary antibody at $4{ }^{\circ} \mathrm{C}$. The membrane was then washed thrice with TBS-T for $10 \mathrm{~min}$ each and incubated with the appropriate HRP-conjugated secondary antibody for $1 \mathrm{~h}$ at room temperature. The membrane was washed again (three times with TBS-T, $10 \mathrm{~min}$ each) and then developed using enhanced chemiluminescence (ECL clarity, Biorad) and quantified using Chemidoc MP Imaging system (Biorad).

\subsection{Statistical Analysis}

Statistical analyses were performed by student's $t$-test for either paired or unpaired observations. For multiple comparisons, ANOVA was used-either one-way ANOVA (with Dunnett's post hoc test) or two-way ANOVA (with Tukey-Kramer's post hoc test). Except for Western blotting, experiments were performed at least three times, and each time was made of triplicate wells. The average of the triplicate from each experiment (individual mean) was calculated, and these means were then averaged. Data were presented as mean \pm standard error of the mean (SEM). A $p$-value of less than 0.05 was considered as significant.

\section{Results}

\subsection{MP Inhibits FBS-Induced VSMC Proliferation}

Cells were stimulated with FBS then were treated with or without MP. MP inhibited proliferation in a concentration- and time-dependent manner (Figure 2A). At the concentrations of 200 and $300 \mu \mathrm{M}$, MP significantly reduced the number of viable cells at 24, 48, and $72 \mathrm{~h}$. However, the lowest MP concentration $(100 \mu \mathrm{M})$ caused a significant reduction only at 48 and $72 \mathrm{~h}(100 \mathrm{vs} 83 \%$ and $100 \mathrm{vs} 77 \%$ respectively; $p<0.05$ for both). A similar result was observed when FBS-unchallenged (i.e., quiescent) cells were treated with increasing concentrations of MP $(100,200$, and $300 \mu \mathrm{M})$ (Figure 2B). This suggests that MP inhibits basal and FBS-induced proliferation of these cells.

In order to determine whether the anti-proliferative effect of MP is associated with a change in DNA synthesis, BrdU incorporation assay was employed. MP slightly but significantly decreased basal BrdU incorporation (100 vs 88\%; $p<0.05$ ) (Figure $2 \mathrm{C}$ ). As expected, FBS induced a significant increase in DNA synthesis (100 vs $258 \pm 28 \%$; $p<0.05$ ) (Figure 2 C). This increase was potently diminished by MP $(258 \pm 28 \%$ vs $140 \pm 20 \% ; p<0.01)$. These results are in line with the anti-proliferative effect of MP evaluated by MTT.

\subsection{MP Induces Cell Cycle Arrest of FBS-Induced VSMC}

Having established that MP attenuates FBS-induced cell proliferation, we next sought to assess the effect of MP on cell cycle progression. As shown in Figure 3A, MP increased the $G_{0} / G_{1}$ cell population, while decreasing those in the $S$ and $G_{2} / M$ phases. Expectedly, treatment with FBS decreased the percentage of cells in $G_{0} / G$ and increased the percentage of cells in the $S$ phase (Figure $3 \mathrm{~A}$ ). These FBS-induced changes in the cell cycle profile were attenuated by pretreatment with MP. This indicates that MP inhibited cell proliferation by arresting the cells in the $G_{0} / G_{1}$ phase. 
A.
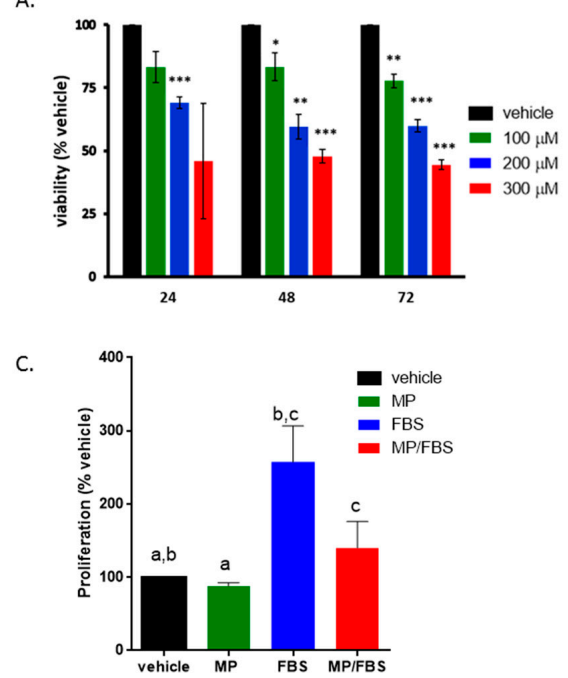

B.

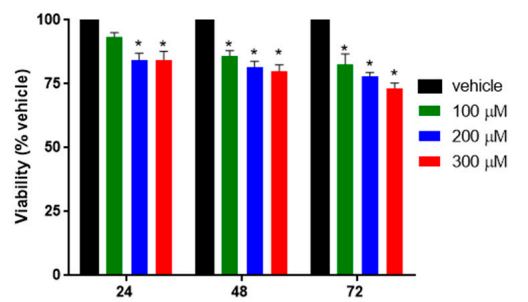

Figure 2. MP attenuates basal and (fetal bovine serum) FBS-induced vascular smooth muscle cells (VSMC) proliferation. Cells were treated with increasing concentrations of MP $(100,200$, and $300 \mu \mathrm{M})$ for 24,48 , and $72 \mathrm{~h}$ in the presence (A) or absence (B) of FBS. Cell viability was assessed by the overall metabolic activity measured by MTT. ${ }^{*} p<0.05,{ }^{* *} p<0.01$ and ${ }^{* * *} p<0.005$. Two-way ANOVA was performed. (C) Cells were grown in starvation or complete medium, in presence or absence of MP $(100 \mu \mathrm{M})$. DNA synthesis was assessed BrdU incorporation assay. Values are calculated as \% of the corresponding vehicle control value and represented as mean \pm standard error of the mean (SEM) of three different experiments, each run in triplicate. Bars with same letters are statistically significant. One-way ANOVA followed by Tukey's test was performed.

A.

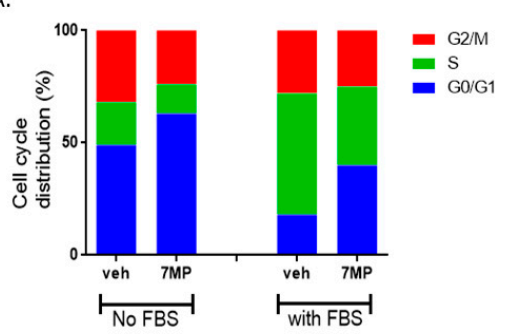

B.

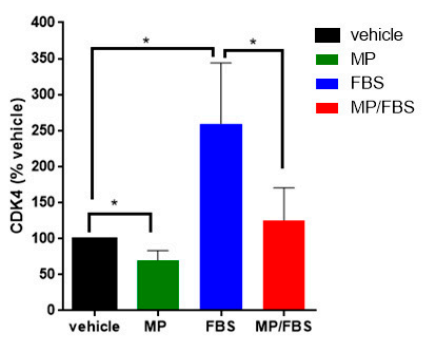

c.

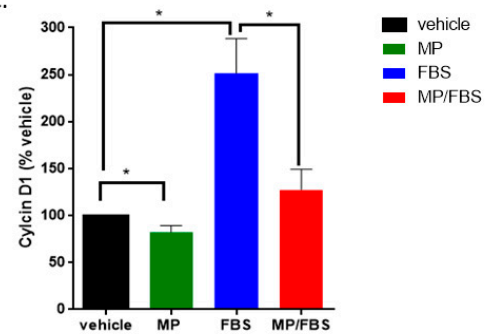

D.

$$
\text { ctrl } \frac{M P(100 \mu M)}{24 \quad 48 \quad 72} \text { hrs }
$$

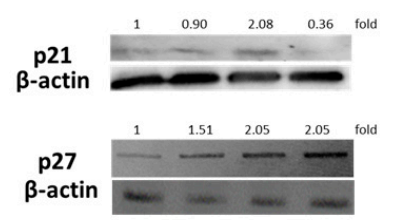

Figure 3. MP blocks VSMCs in $\mathrm{G}_{0} / \mathrm{G}_{1}$ phase of cell cycle. (A) Cells were treated with MP $(100 \mu \mathrm{M})$ for $48 \mathrm{~h}$, stained with PI, then sorted by flow cytometer. Data represent the mean of three independent experiments. (B) and (C) Cells were grown in starvation or complete medium, in presence or absence of MP $(100 \mu \mathrm{M})$. The expression levels of CDK4 (B) and Cyclin D1 (C) were determined by RT-PCR. Values are calculated as \% of the corresponding vehicle control value and represented as mean \pm SEM of three replicates. ( $\left.{ }^{*} p<0.05\right)$. (D) Cells were treated with MP $(100 \mu \mathrm{M})$ for 24,48 , and $72 \mathrm{~h}$. The expression of p21 and p27 was detected by Western blotting. Values mean fold change of three replicates. One-way ANOVA followed by Tukey's test was performed for all panels. 
3.3. MP Downregulates the Expression of Cyclin D1 and CDK4 and Upregulates the Expression of CDK Inhibitors, $p 21$ and $p 27$, in VSMCs

To further validate our results, we sought to characterize the changes in the expression of factors directly involved in cell cycle regulation. Here, we looked at the expression level of cyclin D1, CDK4, p21 and p27. RT-PCR analysis showed that MP significantly decreased the mRNA level of cyclin D1 and CDK4 (Figure 3B,C). As expected, treatment with FBS induced an increase in the transcript level of both cyclin D1 (100 vs $252 \pm 21 \% ; p<0.05)$ and CDK4 (100 vs $259 \pm 49 \% ; p<0.05$ ) (Figure 3B,C). This increase was abrogated by MP $(252 \pm 21 \%$ vs $127 \pm 12 \%$ for cyclin D1 or $259 \pm 49 \%$ vs $125 \pm 26 \%$ for CDK4) (Figure 3B,C). Furthermore, MP induced an increase in the expression of p21 and p27 (Figure 3D). While the upregulation of p21 was noticeable at 24 and $48 \mathrm{~h}$ (Figure 3D), p27 was upregulated only after $48 \mathrm{~h}$ of treatment with MP (Figure 3D). These results further reinforce our hypothesis that MP attenuates FBS-induced cell cycle progression by inhibiting the escape from $\mathrm{G}_{1}$ phase.

\subsection{MP Induces VSMC Apoptosis}

It is well-established that cellular morphologic changes greatly reflect as well as affect cellular function [36-38]. For instance, cells undergoing apoptosis show distinguished morphological features such as cell shrinkage and cytoplasmic extensions [39]. Light microscopic examination of MP-treated cells revealed morphological changes indicative of a loss in the VSMC characteristic spindle shape. These changes occurred 48 and $72 \mathrm{~h}$ post treatment (Figure $4 \mathrm{~A}$ ). Indeed, cells adopted a round translucent morphology (Figure 4A), likely indicative of cell death. Higher magnification showed shrunken and smaller-sized cells (Figure 4B). Moreover, treated cells exhibited long string-like cytoplasmic extensions with blebs attached to their ends (Figure 4C; red arrows). All these changes are characteristic of apoptotic cells $[40,41]$. Using SEM, the cellular ultrastructure revealed the presence of cytoplasmic protrusions known as apoptopodia (Figure 4D; red arrows). Collectively, these observations indicate that MP induces apoptosis of microvascular smooth muscle cells.

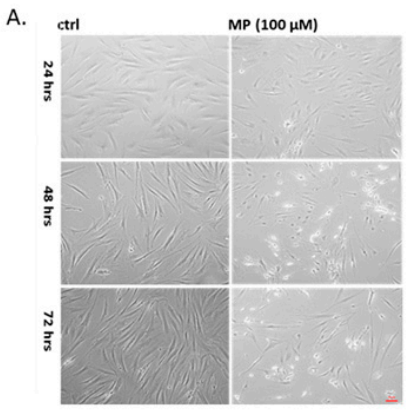

D.

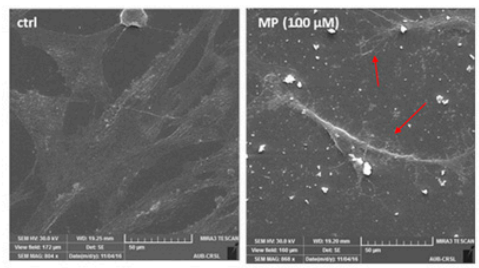

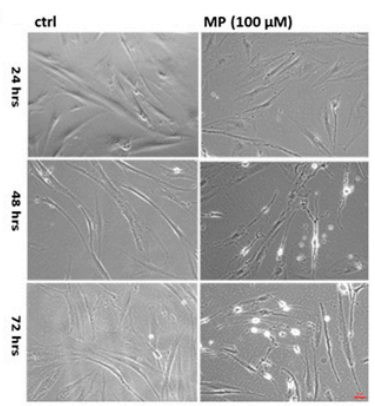

E.
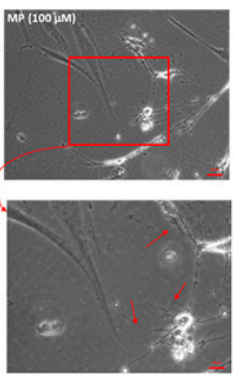

$\mathrm{MP}(100 \mu \mathrm{M})$

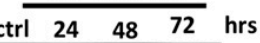

Caspase-3

$\beta$-actin
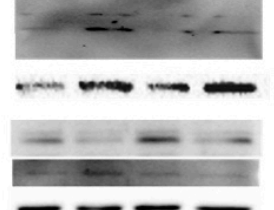

Figure 4. MP induces VSMC apoptosis. Cells were treated with MP $(100 \mu \mathrm{M})$ for 24,48 , and $72 \mathrm{~h}$. Micrographs were captured at magnifications of (A) $4 \times$, (B) $10 \times$, and (C) $20 \times$. (C) The area in the red square was captured at $100 \times$ magnification (lower micrograph). (D): Representative SEM images of MP-treated cells. Scale bars, $50 \mu \mathrm{m}$. In (C) and (D): Red arrows point at cytoplasmic extensions. (E) Cells were treated with MP $(100 \mu \mathrm{M})$ for 24,48 , and $72 \mathrm{~h}$. Activation of caspase- 3 and the expression levels of Bax and Bcl2 were detected by Western blotting. Values mean fold change of three independent experiments. One-way ANOVA followed by Tukey's test was performed. 
To validate our finding, we determined the effect of MP on caspase- 3 cleavage and Bax/Bcl2 ratio. We found that caspase-3 was not activated in MP-treated VSMC for $24 \mathrm{~h}$ (Figure 4E). This result is in agreement with cell viability results and cell morphology images. However, longer exposure (48 and $72 \mathrm{~h}$ ) to MP activated apoptotic cell death revealed by the cleavage of caspase 3 (Figure 4E). In addition, MP induced an increase in the Bax/Bcl2 ratio after 48 or $72 \mathrm{~h}$ of treatment (Figure $4 \mathrm{E}$ ), suggesting the activation of the intrinsic apoptotic pathway.

\subsection{MP Attenuates FBS-Induced VSMC Migration, Invasion, and Adhesion}

The effect of MP on FBS-induced migration was examined using scratch assay. MP, at a concentration of $100 \mu \mathrm{M}$, significantly attenuated wound-healing $(p<0.05)$ after $12 \mathrm{~h}$ (Figure $5 \mathrm{~A}, \mathrm{~B})$. At this time point, no cytotoxic effect of MP was observed (data not shown) (Figure 5A,B), indicating that the anti-migratory capacity is independent of MP's anti-proliferative effect. In addition, we evaluated the effect of MP on the invasive capacity of VSMCs using Matrigel-coated Boyden chambers. Our results showed that MP inhibited FBS-induced invasiveness (Figure 5C).

A.

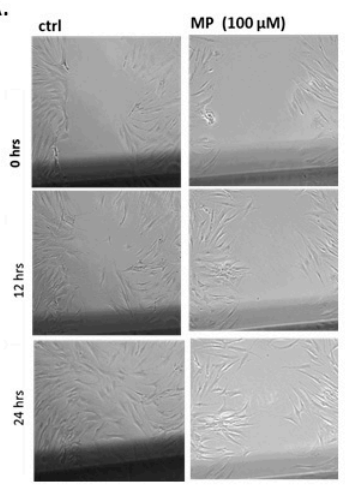

C.

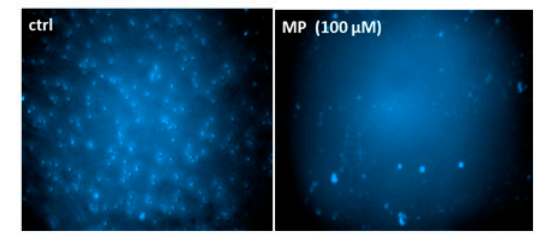

B.
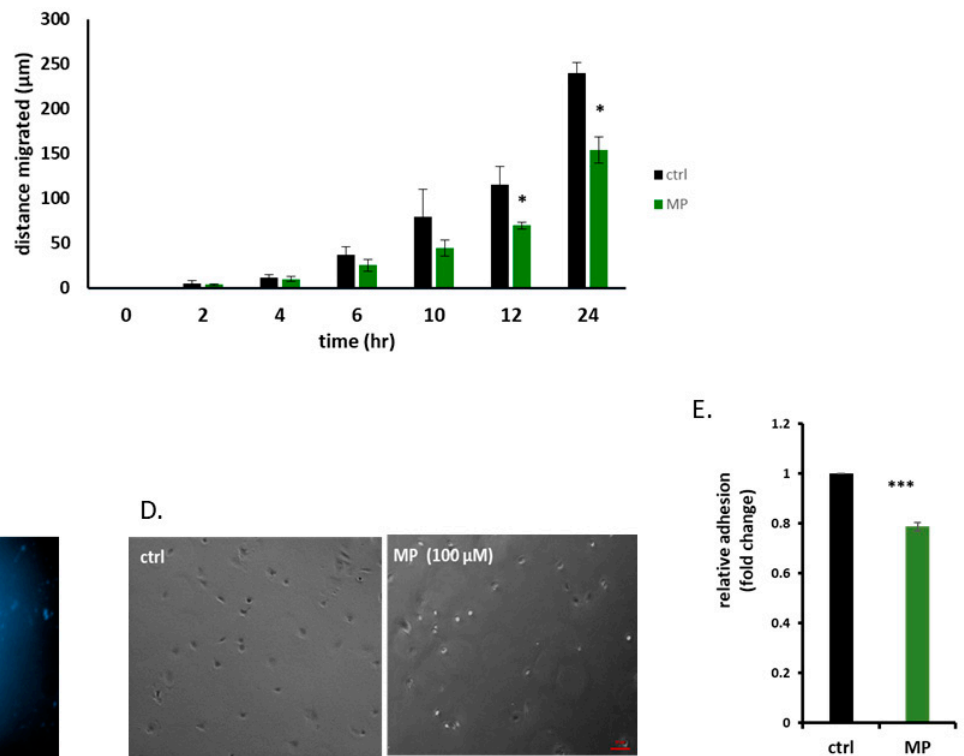

Figure 5. MP inhibits VSMC migration, invasion, and adhesion. (A) Cells were treated with MP $(100 \mu \mathrm{M})$ and cell migration was assessed by scratch assay. Images were taken at the indicated time points (Scale bar, $50 \mu \mathrm{m}$ ). (B) Values are represented as mean \pm SEM of distance migrated $(n=3$ replicates) $\left({ }^{*} p<0.05\right)$. (C) Cells were treated with MP $(100 \mu \mathrm{M})$. Cell invasion was evaluated using invasion assay. Representative photomicrographs showing the effect of MP on invading cells. (D) Cells were treated with MP $(100 \mu \mathrm{M})$ and allowed to adhere for $1 \mathrm{hr}$. Representative photomicrographs of the effect of MP on VSMC adhesion. Scale bar, $50 \mu \mathrm{m}$. (E) Values are represented as mean \pm SEM of relative fold inhibition of vehicle-treated cells $\left({ }^{*} p<0.05\right)$. One-way ANOVA was performed for all panels.

Because cell adhesion to its substratum is critical for cell migration and invasion, we next determined the effect of MP on VSMC adhesion. We found that MP significantly inhibited VSMC adhesion as shown in Figure 5D,E.

\subsection{MP Inhibits MMP-2 and MMP-9 Secretion in VSMCs}

Matrix metalloproteases-2 and -9 (MMP-2 and MMP-9) are known to play a major role in vascular remodeling. Specifically, the activation of MMP-2 and MMP-9 in response to inflammatory stimuli leads to ECM degradation, thus facilitating VSMC migration and invasion [42-44]. Here, our results 
show that MP significantly decreased the levels of secreted MMP-2 and MMP-9. Specifically, MP slightly but significantly reduced basal levels of secreted MMP-2 (100 vs $89 \pm 3 \% ; p<0.05$ ) (Figure 6A) and MMP-9 (100 vs $83 \pm 2 \% ; p<0.05$ ) (Figure $6 \mathrm{~B}$ ). Stimulation with FBS induced a profound increase in MMP-2 (100 vs $283 \pm 12 \% ; p<0.01$ ) and MMP-9 (100 vs $307 \pm 9 \% ; p<0.01$ ) (Figure 6A,B). This increase was significantly attenuated by pretreatment with MP (283 $\pm 12 \%$ vs $150 \pm 11 \%$ or $307 \pm 9 \%$ vs $157 \pm 22 \%$, for MMP-2 and MMP-9 respectively; $p<0.01$ for both) (Figure $6 \mathrm{~A}, \mathrm{~B}$ ).

A.

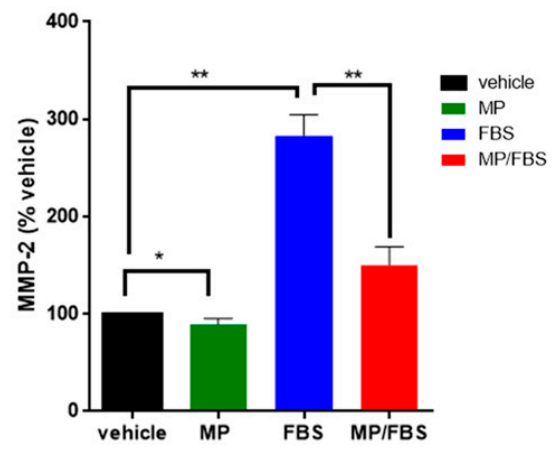

B.

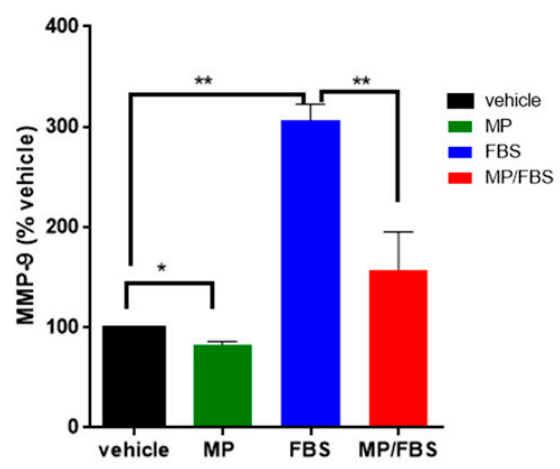

Figure 6. MP inhibits basal and FBS-induced MMP-2 and MMP-9 secretion. Cells were grown in starvation or complete medium, in presence or absence MP $(100 \mu \mathrm{M})$. Levels of secreted MMP-2 (A) and MMP-9 (B) were evaluated by ELISA. Data represented are mean \pm SEM of \% MMP level in the corresponding vehicle-treated well. $\left({ }^{*} p<0.05,{ }^{* *} p<0.01\right)$. One-way ANOVA followed by Tukey's test was performed.

\subsection{MP Decreases the Phosphorylation of ERK1/2 and FAK}

Activation of the ERK1/2 pathway plays a key role in VSMC proliferation and migration [45-47]. In addition, FAK activation is associated with cell migration and adhesion [48]. Thus, we investigated the effect of MP on the phosphorylation of ERK and FAK using Western blotting. We found that MP induced a decrease in ERK1/2 phosphorylation in a time-dependent manner (Figure 7). Moreover, FAK phosphorylation decreased as early as $10 \mathrm{~min}$ post-MP treatment (Figure 7).

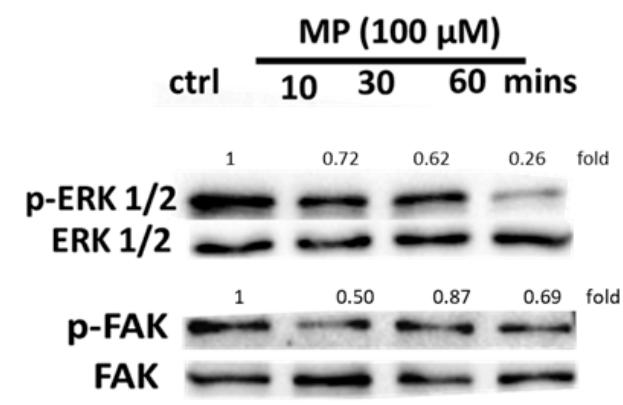

Figure 7. MP attenuates ERK1/2 and FAK phosphorylation in a time-dependent manner. Cells were treated with MP $(100 \mu \mathrm{M})$ for 10, 30, and $60 \mathrm{~min}$. The phosphorylation levels of ERK1/2 and FAK were determined by Western blotting. Values mean fold change of three independent experiments.

3.8. MP Increases the Expression of Early and Mid-Term Differentiation Markers and Decreases the Expression of a De-differentiation Marker

VSMC phenotype, whether contractile or synthetic, may be defined by the level of expression of specific markers. The contractile phenotype is characterized by differentiation markers that are grouped into early, mid-term, and late differentiation markers [49]. On the other hand, synthetic VSMCs secrete many ECM proteins, including osteopontin and osteonectin [50,51]. 
Here, we show that MP significantly increased the expression of the early differentiation markers, SM22- $\alpha$, SM $\alpha$-actin, and myocardin (100 vs $197 \pm 16 \%$; 100 vs $181 \pm 20 \%$; or 100 vs $222 \pm 22 \%$; for SM22- $\alpha$, $\mathrm{SM} \alpha$-actin, and myocardin respectively; $p<0.01$ for all) in quiescent cells (Figure $8 \mathrm{~A}-\mathrm{C}$ ). As expected, treatment with FBS induced a decrease in the expression of these markers. This decrease was greatly attenuated by MP (FBS alone versus FBS plus MP: $43 \pm 8 \%$ vs $110 \pm 14 \% ; 51 \pm 8 \%$ vs $142 \pm 12 \%$; or $41 \pm 10 \%$ vs $160 \pm 19 \%$; for SM22- $\alpha$, SM $\alpha$-actin, or myocardin respectively; $p<0.01$ for all). Similar results were obtained for mid-term differentiation markers, calponin and caldesmon (Figure 8D) Moreover, MP abrogated the basal (100 vs $67 \pm 14 \% ; p<0.01)$ and FBS-induced $(223 \pm 18 \%$ vs $118 \pm 9 \% ; p<0.01)$ expression of osteopontin, a glycoprotein secreted by synthetic VSMCs (Figure 8E). These results indicate that MP drives VSMCs towards a contractile phenotype via increasing the expression of differentiation markers and decreasing the expression of osteopontin in quiescent and FBS-induced cells.

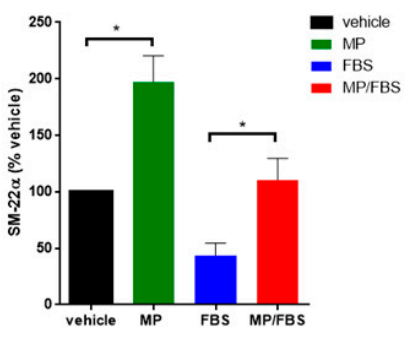

D.

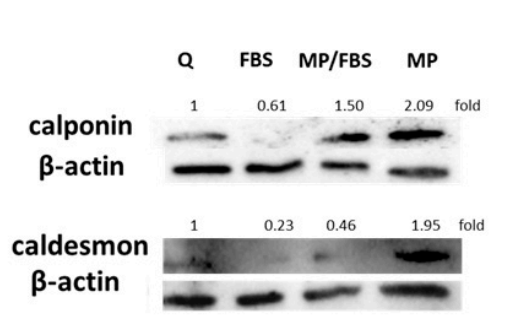

B.

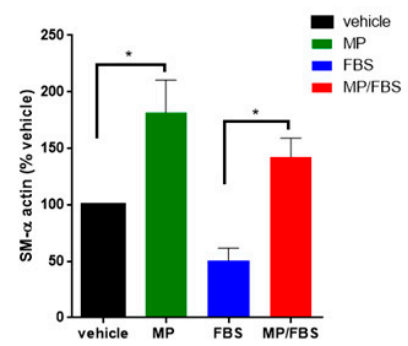

E.

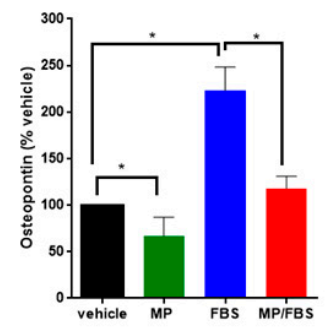

c.

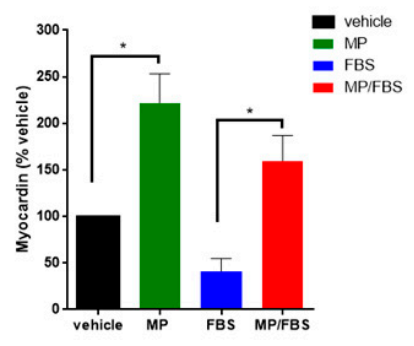

Figure 8. MP increases the expression of basal and FBS-attenuated differentiation markers and decreases basal and FBS-induced expression of osteopontin. Cells were grown in starvation or complete medium, in presence or absence MP $(100 \mu \mathrm{M})$. Expression levels of contractile differentiation markers (A) SM-22 $\alpha$, (B) SM- $\alpha,(C)$ myocardin were evaluated by RT-PCR. Values represented are mean $\pm \mathrm{SEM}$ of $\%$ vehicle control. ( $\left.{ }^{*} p<0.05\right)$. (D) Cells were grown in starvation or complete medium, in presence or absence MP $(100 \mu \mathrm{M})$. The expression of differentiation markers, calponin and caldesmon, was determined by Western blotting. Values mean fold change of three independent experiments. (E) Cells were grown in starvation or complete medium, in presence or absence MP $(100 \mu \mathrm{M})$. The expression level of osteopontin was asssessed by RT-PCR. Values represented are mean $\pm \mathrm{SEM}$ of $\%$ vehicle control. $\left({ }^{*} p<0.05\right)$. One-way ANOVA followed by Tukey's test was performed.

\subsection{MP Inhibits Actin Polymerization}

The actin cytoskeleton in VSMCs is dynamic and responds to external stimuli by polymerization of globular (G) actin to filamentous (F) actin [52]. To test the effect of MP on FBS-induced actin polymerization, phalloidin stain was employed. Phalloidin binds to F-actin and prevents their depolymerization. As expected, FBS treatment induced actin polymerization. This FBS-induced polymerization was inhibited by MP pretreatment as shown in Figure 9. 

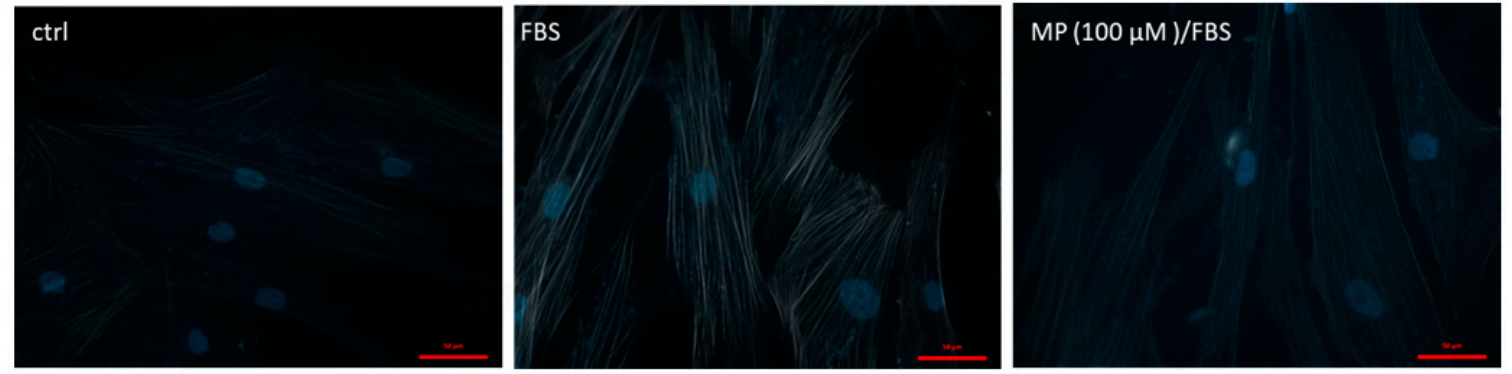

Figure 9. MP attenuates FBS-induced actin polymerization. Cells were treated with FBS for $24 \mathrm{~h}$ in the presence or absence of MP $(100 \mu \mathrm{M})$. Cells were then stained with phalloidin and actin polymerization was assessed. Representative micrographs showing the effect of MP on FBS-induced actin-polymerization. Scale bar, $50 \mu \mathrm{m}$.

\subsection{MP Inhibits PMA-induced Adhesion of THP-1 Monocytes on VSMCs}

Monocyte adhesion to VSMC takes place in many vasculopathies including atherosclerosis, thrombosis, and restenosis [53]. We sought to determine the effect on MP on monocyte adhesion to PMA-induced VSMCs. Toward this, THP-1 cells were incubated with PMA-stimulated VSMCs, with or without pretreatment with MP. In the absence of PMA, the number of THP-1 cells adhered to VSMCs was expectedly minimal. However, stimulation of VSMCs with PMA for $20 \mathrm{~h}$ lead to significant increase in the number of adherent THP-1 cells (Figure 10A). Indeed a 3-fold increase in monocyte adhesion was observed under these conditions (Figure 10B). Interestingly, this increase was completely abolished when VSMC were pretreated with $100 \mu \mathrm{M}$ of MP (Figure 10A,B).

A.

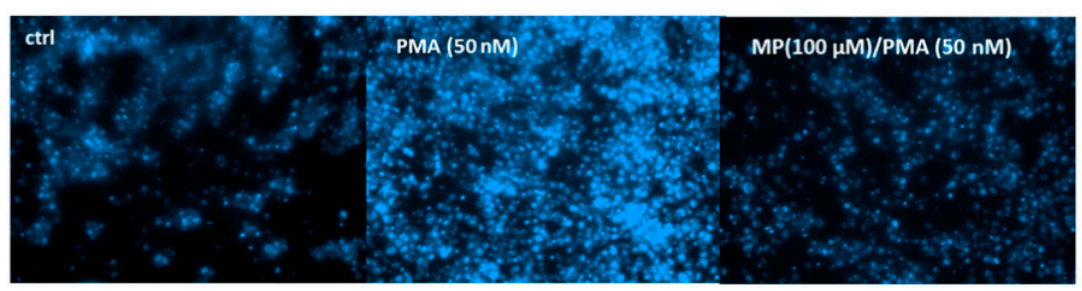

B.

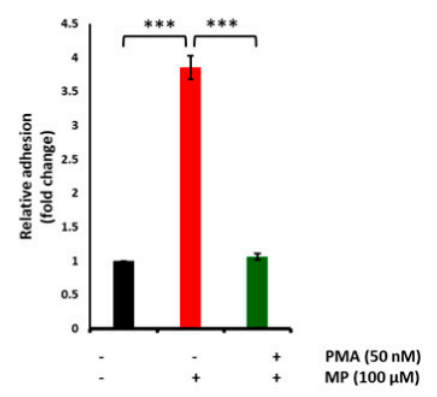

Figure 10. MP abolishes phorbol myristate acetate (PMA)-evoked adhesion THP-1 cells to VSMCs. Cells were treated with PMA (50 nM) in presence or absence of MP (100 $\mu \mathrm{M})$, and adhesion of THP-1 cells was examined by monocyte adhesion assay (A). Representative photomicrographs of the effect of MP on THP-1 adhesion to VSMC. (B) Quantitation of mean fluorescence intensity of adherent THP-1, assessed at 5 different regions; ${ }^{* * *} p<0.001$. Values are represented as mean \pm SEM of relative fold adhesion of vehicle-treated cells. One-way ANOVA followed by Tukey's test was performed. 


\subsection{MP Inhibits FBS-Induced Expression of NF- $\kappa B$ in a Concentration-Dependent Manner}

$\mathrm{NF}-\mathrm{kB}$ transcription factor is a key regulator of vascular inflammatory responses [54]. Here, the effect of MP on the expression of NF- $\mathrm{kB}$ and the phosphorylation of its inhibitor protein, IкB, were evaluated. As shown in Figure 11A, FBS evoked a significant increase in NF- $\mathrm{kB}$ transcription (100 vs $288 \pm 62 \% ; p<0.05$ ). This increase was attenuated by MP in a concentration-dependent manner $(288 \pm 62 \%$ vs $138 \pm 19 \%, 111 \pm 6 \%$ or $87 \pm 9 \%$ for 100,200 , and $300 \mu \mathrm{M}$ respectively; $p<0.01$ for all). Western blotting analysis showed that whereas FBS induced an increase in NF- $\mathrm{KB}$ expression, pretreatment with MP abolished its activation in a time-dependent manner (Figure 11B). Furthermore, pretreatment with MP inhibited FBS-induced phosphorylation of IkB $\alpha$ (Figure 11B).

A.

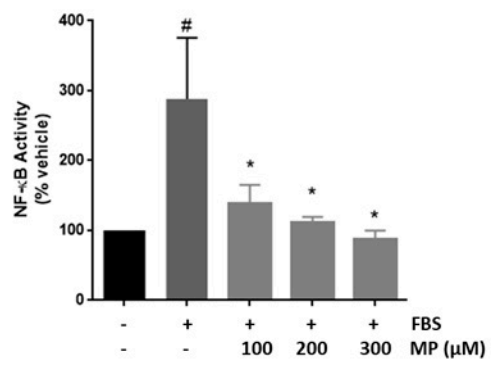

B.

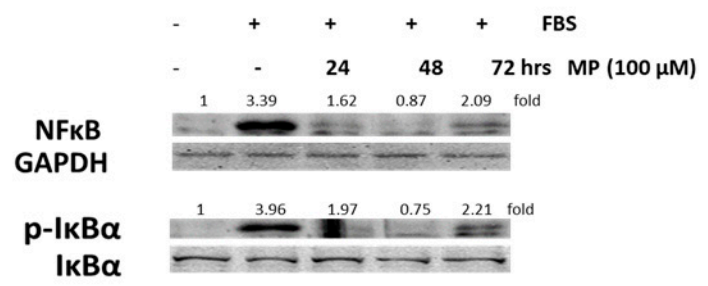

Figure 11. MP inhibits FBS-induced NF- $\kappa B$ expression in a time- and concentration-dependent manner, and attenuates the activation of its inhibitor, $I \kappa B \alpha$. (A) Cells were treated with FBS in the absence or presence of increasing concentrations of MP $(100,200$, and $300 \mu \mathrm{M})$. NF- $\mathrm{kB}$ expression was determined by luciferase assay. Values represented are mean \pm SEM. \# denotes $p<0.05$ (FBS versus vehicle) and * denotes $p<0.05$ (MP + FBS vs FBS)). (B) Cells were treated with FBS in the presence or absence of MP $(100 \mu \mathrm{M})$ for 24,48 , and $72 \mathrm{~h}$. Expression of NF- $\mathrm{KB}$ and phosphorylation of IKB $\alpha$ were detected by Western blotting. Values mean fold change of three independent experiments. One-way ANOVA followed by Tukey's test was performed.

\section{Discussion}

Inflammation of arterioles has recently emerged as a key event in the manifestation of many diseases $[1,55,56]$. These include diabetes and inflammation-based disorders such as chronic obstructive pulmonary disease, inflammatory bowel diseases, cystic fibrosis, and atherosclerosis. Importantly, studies show that changes in arterioles in response to hypercholesterolemia predate the formation of atherosclerotic plaques in large arteries [57]. Moreover, cardiovascular risk factors such as obesity and hypertension induce inflammatory responses at the level of arterioles [58-62]. In response to inflammatory cues, VSMCs acquire increased proliferative, migratory and invasive capabilities. Accordingly, inhibiting these dedifferentiation hallmarks would confer anti-inflammatory effects on arterioles.

In this study, we assessed the vasculoprotective role of MP against FBS-induced arteriolar SMC inflammation, a model mimicking mild arteriolar inflammation. Our results showed that MP, a novel homo-isoflavonoid that we isolated and characterized, inhibited FBS-induced proliferation and migration of human arteriolar smooth muscle cells. Moreover, MP attenuated VSMC adhesion and invasion as well as monocyte adhesion to VSMCs. This inhibition was concomitant with a decrease in matrix metalloproteases, MMP-2 and MMP-9, as well as an increase in the expression of myocardin, SM-22 $\alpha$, SM- $\alpha$ actin, calponin and caldesmon. On the other hand, MP decreased the expression of osteopontin, and abolished FBS-induced NF- $\mathrm{kB}$ expression and IkB phosphorylation.

The significance of this study stems from three points: the novelty of the studied compound, the concentration used to conduct the experiments, and the relevance of the employed model. First, MP is a newly isolated and characterized homoisoflavonoid. Its potential vasculoprotective effects are established for the first time in this study. Moreover, MP proved to be potent at a sub-cytotoxic 
concentration. This may be promising especially in developing a noncytotoxic drug, which may have no or fewer side effects. To our knowledge, this is the first study using human arteriolar SMC as a model for arteriolar inflammation. Previous studies addressing vascular inflammation had used VSMCs extracted from large vessels. This is likely due to the challenging technical difficulty of isolating and maintaining a culture of microvascular smooth muscle cells isolated from human arterioles.

The origin of the VSMC greatly affect its response to various stimuli. For instance, studies reporting the effect of estrogen on VSMCs differ in different vascular beds. To address this, we recently published a paper where we elaborated on the effect of the vascular bed on various functional responses [63]. More relevantly, certain diseases such as retinopathies and kidney diseases affect arterioles rather than large vessels. Accordingly, microvascular SMCs would be a better model to recapitulate many aspects of these pathophysiological cues. However, whether MP effects mirror this vascular bed discrepancy remains to be established.

Overwhelming evidence shows that increased cell proliferation is a hallmark of VSMC phenotypic switch, especially in response to inflammation [64,65]. In our study, MP attenuated FBS-induced VSMC proliferation by blocking cells in the $G_{0} / G_{1}$ phase and inhibiting their progression to $S$ phase. Progression from the G1 to $S$ phase requires cyclin D1 [66,67]. Early in G1, cyclin D1 binds to CDK4. The resulting cyclin D1-CDK4 complex inhibits retinoblastoma protein, thus facilitating the transcription of S-phase genes [68]. Moreover, the activity of cyclin D1-CDK4 complex is inhibited by CDK inhibitors such as p21 and p27 [68]. Here, MP-induced cell cycle arrest was concomitant with an increase in the expression of CDK inhibitors, p21 and p27, as well as a decrease in both cyclinD1 and CDK4.

The anti-proliferative effect of MP is in accordance with the results of two previous studies. The first study reported that brazilin, a homoisoflavonoid, inhibited PDGF-induced proliferation of rat aortic VSMCs and induced cell-cycle arrest at $G_{0} / G_{1}$ phase [69]. The other study showed that the homoisoflavonoid-rich plant, Ophiopogon japonicas, exhibited anti-proliferative effects on thrombin-induced rat aortic VSMCs [70]. Similar to brazilin and Ophiopogon japonicas, MP induced the upregulation of p27 [69,70]. This suggests that homoisoflavonoids attenuate VSMC proliferation by targeting cell cycle regulators. Notably, p27 and p21 are regulated by ERK1/2 [71], which is a mitogenic factor itself [72]. Indeed, pharmacological [73] and genetic [47] inhibition of ERK1/2 inhibit VSMC proliferation. Here, MP attenuated FBS-induced phosphorylation of ERK1/2. This inhibition is in line with the effect of brazilin in VSMCs [69].

Clinically, arteriolar SMC proliferation has been previously assessed in two pathological conditions: hypertension [74] and menorrhagia [75]. VSMCs cultured from rat renal preglomerular arterioles showed that Angiotensin II significantly increased VSMC proliferation, indicating that VSMC hyperplasia may be associated with hypertension [74]. In menorrhagia, endometrial biopsies showed that proliferation of arteriolar SMCs varied between healthy and menorrhagic females [75]. Moreover, arterioles are responsive to pro-inflammatory cues [55], and thus are also remodeled during atherosclerosis by changing their cellular function and phenotype $[55,57,76]$. It is only reasonable to assume that inhibiting VSMC proliferation may aid in the ameliorating microvasculature in these pathological conditions. In this sense, MP, owing to anti-proliferative effect on arteriolar SMCs, presents a promising therapeutic potential at the level of microcirculation.

Many vascular complications arise from the imbalance in the proliferation/apoptosis ratio of VSMCs [77]. For example, VSMCs of diabetic patients have an increased level of the anti-apoptotic protein, Bcl2, and exhibit high proliferative rate [78]. This "failure to die" leads to alteration in the vessel microarchitecture [79]. In our study, MP-treated VSMCs became shrunk and translucent, with fine cytoplasmic extensions ending with blebs. All these features are characteristic of apoptotic cells [80]. These microscopic observations were confirmed by the fact that MP increased $\mathrm{Bax} / \mathrm{Bcl} 2$ ratio and upregulated the level of activated caspase-3. Thus, MP induced apoptosis in FBS-induced micro VSMCs. It would thus be tempting to test whether MP can decrease thickening of muscularized arterioles in pulmonary artery hypertension or chronic obstructive lung disease [81,82]. 
Migration, invasion and adhesion of VSMCs are also major determinants of the dedifferentiated phenotype, and play a major role in vascular pathogenesis [83]. In our study, MP potently attenuated these hallmarks. Knowing that both ERK1/2 and FAK mediate cell migration [46,84], we may assume that MP-attenuated migration is achieved via inhibiting ERK1/2 and FAK phosphorylation. Moreover, in addition to its role in mobilizing adrenergic receptors to the cell surface [85], actin polymerization plays a key role in VSMC migration [52]. During migration, integrins are activated and clustered along with adhesion molecules at the migrating edge of the cell [86]. These cytoskeletal rearrangements along with actin polymerization facilitate cell crawling [87]. In our study, MP attenuated FBS-induced actin polymerization. Furthermore, MP reduced the invasive capacity of VSMCs by attenuating the expression of the matrix metalloprotease of MMP-2 and MMP-9. Previous studies report that VSMC migration was attenuated by the homoisoflavonoid, brazilin, and the homoisoflavonoid-rich plant, Ophiopogon japonicas $[69,70]$. However, these studies neither used human arteriolar cells nor assessed the effects on VSMC adhesion or invasion.

Clinically, arteriolar SMC migration was observed during cardiac transplantation in a condition termed transplant arteriosclerosis [88]. This condition is characterized by inflammation and intimal thickening due to the accumulation of SMCs from both donor and recipient [88]. A study using post-transplantation cardiac biopsy specimens from allograft patients showed that higher arteriolar SMC migration was associated with rejection grade, and thus with inflammation [88]. Here, MP attenuated arteriolar SMC migration. Hence, we may postulate that MP may contribute to reversing arteriolar inflammation and decreasing rejection grade.

Monocyte adhesion to blood vessels is a defining feature of vascular inflammation [89,90]. In response to inflammatory cues, arterioles become more permissive to monocytes, allowing them interact with endothelial cells and VSMCs [55]. Monocyte adhesion may also precipitate arteriolar barrier dysfunction [91]. Indeed, in response to increased luminal shear stress, monocytes are recruited to then adhere onto collateral arterioles [92]. Furthermore, direct evidence of monocyte adhesion to arterioles in response to Angiotensin II has been reported [93]. In our study, we showed that MP attenuated monocyte adhesion to PMA-activated arteriolar SMCs. Because PKC is a direct target of PMA [94], it may be postulated that MP attenuates PMA-provoked adhesion by inhibiting PKC. Indeed, PKC is inhibited by many flavonoids [95]. However, whether MP inhibits PKC is yet to be investigated.

VSMCs are not terminally differentiated, but are rather characterized by plasticity that allows phenotypic switch [96]. The extent of VSMC differentiation is determined by the expression level of differentiation markers. These markers are divided in to early, mid-term, and late differentiation markers, according to their order of appearance during embryogenesis [49]. The early differentiation markers include SM- $\alpha$ actin, myocardin, and SM22- $\alpha$ [49]. Caldesmon and calponin are considered to be mid-term differentiation markers [97]. Finally, desmin and smoothelin are among late differentiation markers [97]. Contractile VSMCs are characterized by the elevated expression of these markers [98]. In response to inflammation, VSMCs reduce the expression of these markers and adopt the expression of synthetic dedifferentiated phenotype [98]. VSMCs then become active in secreting ECM molecules such as osteopontin and osteonectin $[51,99,100]$. As such, high levels of these proteins indicate VSMC switch to synthetic phenotype.

Myocardin is a transcriptional co-activator that acts upstream of calponin and caldesmon. It is selectively expressed in cardiomyocytes and contractile SMCs [101-103]. It is a potent activator of the Serum Response Factor (SRF) where it stabilizes its binding at the CC(A/T-rich) 6 GG (CArG) cis-elements of CArG-dependent genes. Interestingly, expression of VSMC differentiation genes, such as SM22, MHC, $\mathrm{SM} \alpha$-actin and caldesmon requires CArG box in their promoter region and/or intronic sequences $[104,105]$. Nonetheless, some studies report that myocardin-driven expression of CArG-dependent SMC marker genes is not sufficient for the initiation of complete SMC differentiation [106].

In response to stimuli, myocardin regulation of SMC markers expression is attenuated mainly through 2 distinct pathways, both involving ERK1/2 activation. Activated ERK1/2 leads to Elk-1 phosphorylation, which competes with myocardin for SRF, leading to attenuated SMC marker expression [107]. Alternatively, myocardin may be directly phosphorylated by ERK1/2. This ERK1/2-induced myocardin phosphorylation 
hinders its ability to bind SRF and induce marker genes expression [108]. Several other effector pathways have been reported. For example the JAK/STAT signaling mediates VSMC switch to the synthetic phenotype via the interaction between STAT3 and myocardin [109]. Furthermore, Yap1 upregulation promotes synthetic phenotype by reducing myocardin-SRF interaction [110]. Similarly, NF-kB (p65) interacts with myocardin hindering myocardin-SRF interaction necessary for contractile genes expression [111]. Interestingly, myocardin attenuates the expression of NF- $\mathrm{B}(\mathrm{p} 65)$-driven genes [111]. In this sense, the protective role of myocardin lies in orchestrating the expression of SMC differentiation genes and in attenuating the expression of inflammatory genes.

Osteopontin is a glycoprotein secreted by many cell types including osteoblasts, monocytes, and VSMCs [112,113]. Specifically, its expression is increased during the switch of VSMCs to the synthetic phenotype as well as during vascular remodeling [114,115], as it is involved proliferation and migration [116-118]. Osteopontin induces migration by phosphorylating FAK, dephosphorylating downstream ILK, and by disrupting FAK-ILK interaction [118]. In addition, osteopontin leads to decreased expression of differentiation markers such as $\alpha$-SM actin, and calponin [119]. Furthermore, studies show that osteopontin plays a role in vascular inflammation by inducing leukocyte chemotaxis and macrophage adhesion to endothelial cells [115]. Transcription of osteopontin is regulated by NF-кB [120,121].

Whereas previous reports have focused almost exclusively on assessing the expression level of these differentiation markers in macro-VSMCs $[119,122,123]$, our study assessed the expression of these markers in micro-VSMCs. We showed that MP induced an elevation in myocardin, SM- $\alpha, \mathrm{SM}-22 \alpha$, calponin, and caldesmon, and reversed the FBS-attenuated expression of these markers in arteriolar SMCs. In fact, one previous study assessed the phenotypic switch of arteriolar SMCs in the context of benign nephrosclerosis ( $\mathrm{bN})$, a common hypertensive kidney damage characterized by fibrosis of renal arterioles [124]. Using renal tissue specimens, this study showed that arteriolar SMCs undergo a phenotypic switch in bN [124]. Surprisingly, their findings did not suggest an inverse correlation between caldesmon and dedifferentiated VSMCs [124]. Conversely, our results showed the caldesmon and calponin were upregulated by MP in FBS-induced arteriolar SMCs. Moreover, MP effectively decreased the expression of basal and FBS-induced expression osteopontin, further emphasizing the maintenance of a contractile phenotype of VSMCs. In 2018, Lin et al. showed that the flavonoid, (-)-epigallocatechin gallate (EGCG), attenuated Ag-II induced proliferation and migration in vitro and neointimal formation in vivo [125]. These inhibitory effects were mediated by myocardin. Therefore, this and other studies present myocardin as a molecular therapeutic target in vascular inflammation. In light of our results showing its ability to modulate myocardin expression, MP may thus be expected to possess a much-desired anti-inflammatory capacity. Indeed, our unpublished observations strongly suggest such an effect.

NF- $\mathrm{KB}$ is a member of the Rel-family of transcription factors [126]. Under normal physiological conditions, NF- $\kappa B$ is attached to its inhibitor protein I $\kappa$ B which traps it in the cytosol [126]. In response to inflammatory stimuli, IKB gets phosphorylated by its kinase, IKK, then ubiquitinated and degraded [122]. $\mathrm{NF}-\kappa \mathrm{B}$ then becomes free to translocate to the nucleus and trigger the transcription of pro-inflammatory genes $[127,128]$. In vascular inflammation, such as atherosclerosis, NF- $\kappa B$ upregulates the expression of adhesion molecules (ICAM-1and VCAM-1) and matrix-metalloproteases (MMP-2, and MMP-9) [129], further exacerbating vascular inflammation [130]. The vast majority of research show that NF- $\mathrm{KB}$ activates the inflammatory signaling in VSMCs of large vessels [127]. Except for one study showing that NF- $\kappa$ B is expressed and activated in arterioles [131], no previous studies assessed the modulation of NF- $\kappa B$ expression specifically in microVSMCs. Here, we show that NF- $\kappa B$ expression and I $\kappa B$ phosphorylation were attenuated by MP in FBS-activated micro VSMCs. This supports the vascular anti-inflammatory actions of MP and presents NF- $\kappa$ B and $\mathrm{I} \kappa \mathrm{B}$ as major molecular targets in the involved signaling pathway. By doing so, MP may be suppressing many genes such as MMP-2 and MMP-9, in addition to other genes which remain to be investigated. 


\section{Conclusions}

To sum up, our data are consistent with the model shown in Figure 12, which illustrates different lines of action of MP and the involved molecular players. All depicted MP effects serve to attenuate VSMC dedifferentiation and thus may amend arteriolar inflammation. Further research is needed to better dissect the molecular mechanisms implicated in MP signaling. For instance, some flavonoids and isoflavonoids have been shown to regulate cAMP signaling in VSMCs [132,133]. Given the important and broad range of cAMP effects in human microvascular smooth muscle cells [32,34,86,134], if MP appears to modulate this pathway in these cells lines, one would expect to find diverse effects of MP on arteriolar physiology and pathophysiology. Further investigations are warranted to better determine the potential of MP as anti-inflammatory drug especially as pertains to vascular anti-inflammatory therapies. Knowing that modern drug therapy is still insufficient in preventing or treating CVD [135], the use of alternative medicine such as flavonoids and homoisoflavonoids may provide an important resource for potential new drugs.

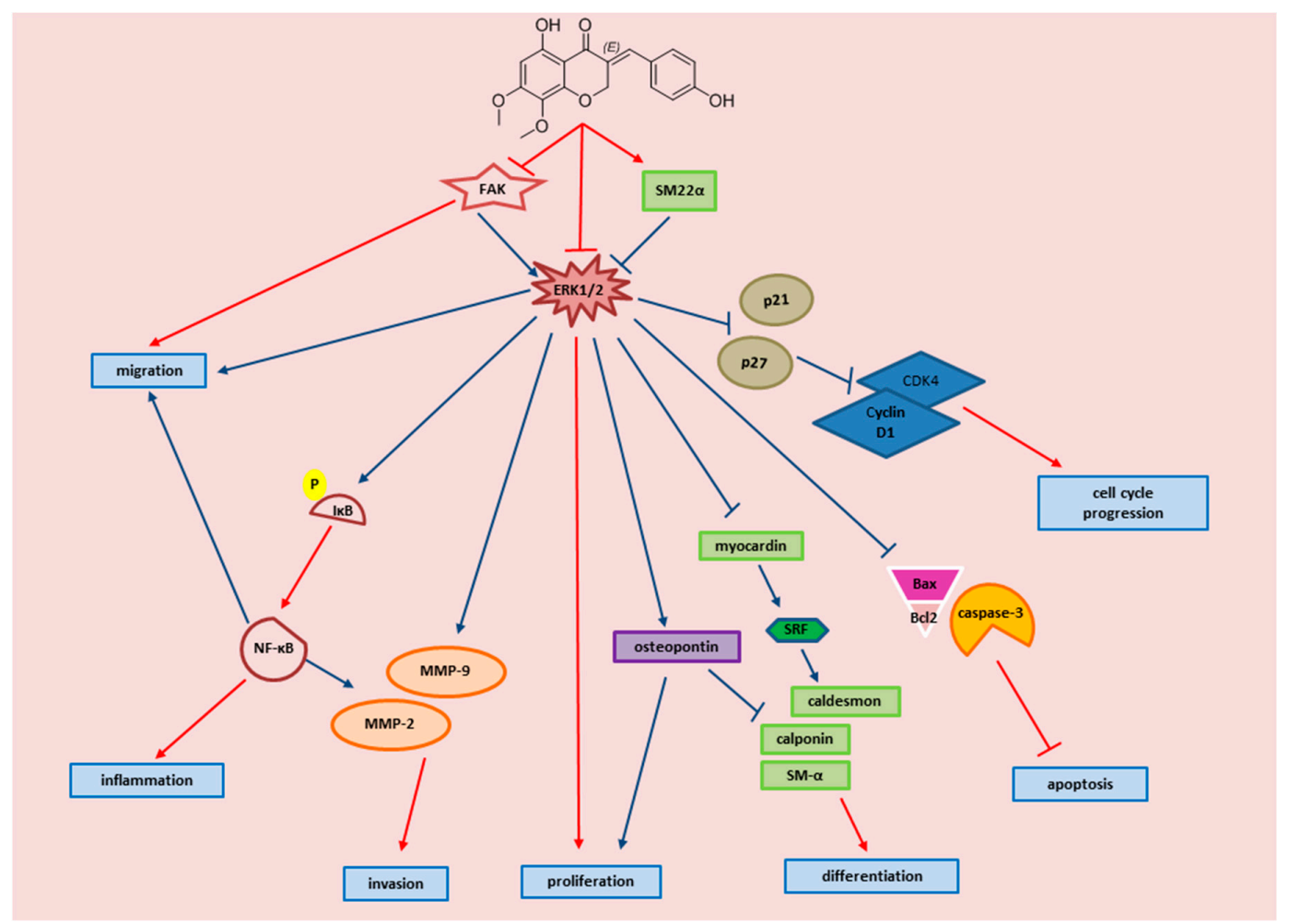

Figure 12. Schematic representation of the proposed signaling pathway by which MP attenuates FBS-induced inflammation of arteriolar SMC. The diagram displays key events of VSMC inflammation, and the molecular effectors by which MP attenuates these events. Red arrows are established by our study, blue arrows are established as referenced below: FAK $\rightarrow$ ERK1/2 [136,137]; SM22 $\alpha \rightarrow$ ERK1/2 [138]; ERk1/2 $\rightarrow$ osteopontin [139]; ERK1/2 $\rightarrow$ p21/p27 [71]; ERK1/2 $\rightarrow$ caspase-3, BAX/Bcl2 [140,141]; Osteopontin $\rightarrow$ proliferation [142]; Osteopontin $\rightarrow \alpha$ SM and calponin [119]; p21, p27 $\rightarrow$ Cyclin D1/CDK4 [143,144]; NF-кB $\rightarrow$ MMP-2, MMP-9 [145-147]; NF-кB $\rightarrow$ proliferation, migration [148]; NF-kB $\rightarrow$ cyclin D1 [127,149].

Author Contributions: Conceptualization, A.H.E.; Data curation, M.F., H.D., and E.B.; Formal analysis, A.E. and A.B.; Funding acquisition, A.B., A.H.E. and E.B.; Methodology, T.G., T.E.-E., and F.A.; Project administration, A.H.E. and E.B.; Resources, E.B.; Writing—original draft, M.F., R.I., and A.H.E.; Writing-review \& editing, A.H.E. and E.B.

Funding: This work was supported by the American University of Beirut (Grant \# MPP 320133 to A.E.), University of Petra (Grant \#: 5/4/2019) to A.B., E.B., and A.E., and the National Council for Scientific Research (CNRS) to M.F.

Conflicts of Interest: The authors declare no conflict of interest. 


\section{References}

1. Pober, J.S.; Sessa, W.C. Inflammation and the blood microvascular system. Cold Spring Harb. Perspect. Biol. 2014, 7, a016345. [CrossRef]

2. Rensen, S.S.; Doevendans, P.A.; van Eys, G.J. Regulation and characteristics of vascular smooth muscle cell phenotypic diversity. Neth. Heart J. 2007, 15, 100-108. [CrossRef] [PubMed]

3. Steucke, K.E.; Tracy, P.V.; Hald, E.S.; Hall, J.L.; Alford, P.W. Vascular smooth muscle cell functional contractility depends on extracellular mechanical properties. J. Biomech. 2015, 48, 3044-3051. [CrossRef] [PubMed]

4. Fardoun, M.M.; Nassif, J.; Issa, K.; Baydoun, E.; Eid, A.H. Raynaud's phenomenon: A brief review of the underlying mechanisms. Front. Pharmacol. 2016, 7, 438. [CrossRef] [PubMed]

5. Gomez, D.; Owens, G.K. Smooth muscle cell phenotypic switching in atherosclerosis. Cardiovasc. Res. 2012, 95, 156-164. [CrossRef] [PubMed]

6. Tachiian, A.; Maria, V.; Jahangir, A. Use of herbal products and potential interactions in patients with cardiovascular diseases. J. Am. Coll. Cardiol. 2010, 55, 515-525. [CrossRef]

7. Li, L.; Zhou, X.; Li, N.; Sun, M.; Lv, J.; Xu, Z. Herbal drugs against cardiovascular disease: Traditional medicine and modern development. Drug Discov. Today 2015, 20, 1074-1086. [CrossRef]

8. McCullough, M.L.; Peterson, J.J.; Patel, R.; Jacques, P.F.; Shah, R.; Dwyer, J.T. Flavonoid intake and cardiovascular disease mortality in a prospective cohort of US adults. Am. J. Clin. Nutr. 2012, 95, 454-464. [CrossRef]

9. van Dam, R.M.; Naidoo, N.; Landberg, R. Dietary flavonoids and the development of type 2 diabetes and cardiovascular diseases: Review of recent findings. Curr. Opin. Lipidol. 2013, 24, 25-33. [CrossRef]

10. Mozaffarian, D.; Wu, J.H.Y. Flavonoids, dairy foods, and cardiovascular and metabolic health: A review of emerging biologic pathways. Circ. Res. 2018, 122, 369-384. [CrossRef]

11. Hodgson, J.M.; Croft, K.D. Tea flavonoids and cardiovascular health. Mol. Asp. Med. 2010, 31, 495-502. [CrossRef] [PubMed]

12. Hooper, L.; Kroon, P.A.; Rimm, E.B.; Cohn, J.S.; Harvey, I.; Le Cornu, K.A.; Ryder, J.J.; Hall, W.L.; Cassidy, A. Flavonoids, flavonoid-rich foods, and cardiovascular risk: A meta-analysis of randomized controlled trials. Am. J. Clin. Nutr. 2008, 88, 38-50. [CrossRef] [PubMed]

13. Wang, C.Z.; Mehendale, S.R.; Calway, T.; Yuan, C.S. Botanical flavonoids on coronary heart disease. Am. J. Chin. Med. 2011, 39, 661-671. [CrossRef] [PubMed]

14. Wang, D.; Zhuang, Y.; Tian, Y.; Thomas, G.N.; Ying, M.; Tomlinson, B. Study of the effects of total flavonoids of Astragalus on atherosclerosis formation and potential mechanisms. Oxidative Med. Cell. Longev. 2012, 2012, 282383. [CrossRef]

15. Maaliki, D.; Shaito, A.A.; Pintus, G.; El-Yazbi, A.; Eid, A.H. Flavonoids in hypertension: A brief review of the underlying mechanisms. Curr. Opin. Pharmacol. 2019, 45, 57-65. [CrossRef]

16. Alali, F.; El-Elimat, T.; Albataineh, H.; Al-Balas, Q.; Al-Gharaibeh, M.; Falkinham, J.O., 3rd; Chen, W.L.; Swanson, S.M.; Oberlies, N.H. Cytotoxic homoisoflavones from the bulbs of Bellevalia eigii. J. Nat. Prod. 2015, 78, 1708-1715. [CrossRef]

17. Paudel, K.R.; Karki, R.; Kim, D.W. Cepharanthine inhibits in vitro VSMC proliferation and migration and vascular inflammatory responses mediated by RAW264.7. Toxicol. Vitr. 2016, 34, 16-25. [CrossRef]

18. Aoki, C.; Hattori, Y.; Tomizawa, A.; Jojima, T.; Kasai, K. Anti-inflammatory role of cilostazol in vascular smooth muscle cells in vitro and in vivo. J. Atheroscler. Thromb. 2010, 17, 503-509. [CrossRef]

19. Heiss, E.H.; Liu, R.; Waltenberger, B.; Khan, S.; Schachner, D.; Kollmann, P.; Zimmermann, K.; Cabaravdic, M.; Uhrin, P.; Stuppner, H.; et al. Plumericin inhibits proliferation of vascular smooth muscle cells by blocking STAT3 signaling via S-glutathionylation. Sci. Rep. 2016, 6, 20771. [CrossRef]

20. Lin, L.G.; Liu, Q.Y.; Ye, Y. Naturally occurring homoisoflavonoids and their pharmacological activities. Planta Med. 2014, 80, 1053-1066. [CrossRef]

21. El-Elimat, T.; Rivera-Chavez, J.; Burdette, J.E.; Czarnecki, A.; Alhawarri, M.B.; Al-Gharaibeh, M.; Alali, F.; Oberlies, N.H. Cytotoxic homoisoflavonoids from the bulbs of Bellevalia flexuosa. Fitoterapia 2018, 127, 201-206. [CrossRef] [PubMed]

22. Hung, T.M.; Thu, C.V.; Dat, N.T.; Ryoo, S.W.; Lee, J.H.; Kim, J.C.; Na, M.; Jung, H.J.; Bae, K.; Min, B.S. Homoisoflavonoid derivatives from the roots of Ophiopogon japonicus and their in vitro anti-inflammation activity. Bioorg. Med. Chem. Lett. 2010, 20, 2412-2416. [CrossRef] [PubMed] 
23. Moon, C.K.; Lee, S.H.; Lee, M.O.; Kim, S.G. Effects of Brazilin on glucose oxidation, lipogenesis and therein involved enzymes in adipose tissues from diabetic KK-mice. Life Sci. 1993, 53, 1291-1297. [CrossRef]

24. Wall, M.E.; Wani, M.C.; Manikumar, G.; Taylor, H.; McGivney, R. Plant antimutagens, 6. Intricatin and intricatinol, new antimutagenic homoisoflavonoids from Hoffmanosseggia intricata. J. Nat. Prod. 1989, 52, 774-778. [CrossRef] [PubMed]

25. Niranjan Reddy, V.L.; Ravikanth, V.; Jansi Lakshmi, V.V.; Suryanarayan Murty, U.; Venkateswarlu, Y. Inhibitory activity of homoisoflavonoids from Caesalpinia sappan against Beauveria bassiana. Fitoterapia 2003, 74, 600-602. [CrossRef]

26. Tait, S.; Salvati, A.L.; Desideri, N.; Fiore, L. Antiviral activity of substituted homoisoflavonoids on enteroviruses. Antivir. Res. 2006, 72, 252-255. [CrossRef]

27. Calvo, M.I. Three new homoisoflavanones from the bulbs of Ledebouria floribunda. Fitoterapia 2009, 80, $394-398$. [CrossRef]

28. Wang, D.; Zeng, L.; Li, D.; Pu, W. Antioxidant activities of different extracts and homoisoflavanones isolated from the Polygonatum odoratum. Nat. Prod. Res. 2013, 27, 1111-1114. [CrossRef]

29. Tribble, D.L. AHA Science Advisory. Antioxidant consumption and risk of coronary heart disease: Emphasison vitamin C, vitamin E, and $\beta$-carotene: A statement for healthcare professionals from the American Heart Association. Circulation 1999, 99, 591-595. [CrossRef]

30. Mulholland, D.A.; Schwikkard, S.L.; Crouch, N.R. The chemistry and biological activity of the Hyacinthaceae. Nat. Prod. Rep. 2013, 30, 1165-1210. [CrossRef]

31. Al-Eisawi, D.M. Field Guide to Wild Flowers of Jordan and Neighbouring Countries; Jordan Press Foundation: Amman, Jordan, 1998.

32. Jeyaraj, S.C.; Unger, N.T.; Eid, A.H.; Mitra, S.; Paul El-Dahdah, N.; Quilliam, L.A.; Flavahan, N.A.; Chotani, M.A. Cyclic AMP-Rap1A signaling activates RhoA to induce $\alpha(2 \mathrm{c})$-adrenoceptor translocation to the cell surface of microvascular smooth muscle cells. Am. J. Physiol. Cell Physiol. 2012, 303, C499-C511. [CrossRef] [PubMed]

33. Fardoun, M.; Al-Shehabi, T.; El-Yazbi, A.; Issa, K.; Zouein, F.; Maaliki, D.; Iratni, R.; Eid, A.H. Ziziphus nummularia inhibits inflammation-induced atherogenic phenotype of human aortic smooth muscle cells. Oxidative Med. Cell. Longev. 2017, 2017, 4134093. [CrossRef] [PubMed]

34. Eid, A.H. cAMP induces adhesion of microvascular smooth muscle cells to fibronectin via an Epac-mediated but PKA-independent mechanism. Cell. Physiol. Biochem. 2012, 30, 247-258. [CrossRef] [PubMed]

35. Eid, A.H.; Chotani, M.A.; Mitra, S.; Miller, T.J.; Flavahan, N.A. Cyclic AMP acts through Rap1 and JNK signaling to increase expression of cutaneous smooth muscle alpha(2C)-adrenoceptors. Am. J. Physiol. Heart C 2008, 295, H266-H272. [CrossRef] [PubMed]

36. Häcker, G. The morphology of apoptosis. Cell Tissue Res. 2000, 301, 5-17. [CrossRef]

37. Kamada, R.; Tano, F.; Kudoh, F.; Kimura, N.; Chuman, Y.; Osawa, A.; Namba, K.; Tanino, K.; Sakaguchi, K. Effective cellular morphology analysis for differentiation processes by a fluorescent 1,3a,6a-triazapentalene derivative probe in live cells. PLoS ONE 2016, 11, e0160625. [CrossRef]

38. Shi, P.; Laude, A.; Yeong, W.Y. Investigation of cell viability and morphology in 3D bio-printed alginate constructs with tunable stiffness. J. Biomed. Mater. Res. A 2017, 105, 1009-1018. [CrossRef]

39. Saraste, A.; Pulkki, K. Morphologic and biochemical hallmarks of apoptosis. Cardiovasc. Res. 2000, 45, 528-537. [CrossRef]

40. Elmore, S. Apoptosis: A review of programmed cell death. Toxicol. Pathol. 2007, 35, 495-516. [CrossRef]

41. Atkin-Smith, G.K.; Tixeira, R.; Paone, S.; Mathivanan, S.; Collins, C.; Liem, M.; Goodall, K.J.; Ravichandran, K.S.; Hulett, M.D.; Poon, I.K. A novel mechanism of generating extracellular vesicles during apoptosis via a beads-on-a-string membrane structure. Nat. Commun. 2015, 6, 7439. [CrossRef]

42. Chen, Q.; Jin, M.; Yang, F.; Zhu, J.; Xiao, Q.; Zhang, L. Matrix metalloproteinases: Inflammatory regulators of cell behaviors in vascular formation and remodeling. Mediat. Inflamm. 2013, 2013, 928315. [CrossRef] [PubMed]

43. Uzui, H.; Lee, J.D.; Shimizu, H.; Tsutani, H.; Ueda, T. The role of protein-tyrosine phosphorylation and gelatinase production in the migration and proliferation of smooth muscle cells. Atherosclerosis 2000, 149, 51-59. [CrossRef]

44. Mason, D.P.; Kenagy, R.D.; Hasenstab, D.; Bowen-Pope, D.F.; Seifert, R.A.; Coats, S.; Hawkins, S.M.; Clowes, A.W. Matrix metalloproteinase-9 overexpression enhances vascular smooth muscle cell migration and alters remodeling in the injured rat carotid artery. Circ. Res. 1999, 85, 1179-1185. [CrossRef] 
45. Yu, L.; Huang, X.; Huang, K.; Gui, C.; Huang, Q.; Wei, B. Ligustrazine attenuates the platelet-derived growth factor-BB-induced proliferation and migration of vascular smooth muscle cells by interrupting extracellular signal-regulated kinase and P38 mitogen-activated protein kinase pathways. Mol. Med. Rep. 2015, 12, 705-711. [CrossRef] [PubMed]

46. Gerthoffer, W.T. Mechanisms of vascular smooth muscle cell migration. Circ. Res. 2007, 100, 607-621. [CrossRef] [PubMed]

47. Izumi, Y.; Kim, S.; Namba, M.; Yasumoto, H.; Miyazaki, H.; Hoshiga, M.; Kaneda, Y.; Morishita, R.; Zhan, Y.; Iwao, H. Gene transfer of dominant-negative mutants of extracellular signal-regulated kinase and c-Jun NH2-terminal kinase prevents neointimal formation in balloon-injured rat artery. Circ. Res. 2001, 88, 1120-1126. [CrossRef]

48. Guan, J.L.; Trevithick, J.E.; Hynes, R.O. Fibronectin/integrin interaction induces tyrosine phosphorylation of a 120-kDa protein. Cell Regul. 1991, 2, 951-964. [CrossRef]

49. Han, Y.L.; Xiao, Y.P.; Qi, Y.M.; Kang, J.; Yan, C.H. Expression of vascular smooth muscle cell markers during early stage of embryonic stem cell-derived embryoid bodies differentiation. Zhongguo Ying Yong Sheng Li Xue Za Zhi 2008, 24, 385-390.

50. Giachelli, C.M.; Bae, N.; Almeida, M.; Denhardt, D.T.; Alpers, C.E.; Schwartz, S.M. Osteopontin is elevated during neointima formation in rat arteries and is a novel component of human atherosclerotic plaques. J. Clin. Investig. 1993, 92, 1686-1696. [CrossRef]

51. Trion, A.; van der Laarse, A. Vascular smooth muscle cells and calcification in atherosclerosis. Am. Heart J. 2004, 147, 808-814. [CrossRef]

52. Kim, H.R.; Gallant, C.; Leavis, P.C.; Gunst, S.J.; Morgan, K.G. Cytoskeletal remodeling in differentiated vascular smooth muscle is actin isoform dependent and stimulus dependent. Am. J. Physiol. Cell Physiol. 2008, 295, C768-C778. [CrossRef] [PubMed]

53. Jang, Y.; Lincoff, A.M.; Plow, E.F.; Topol, E.J. Cell adhesion molecules in coronary artery disease. J. Am. Coll. Cardiol. 1994, 24, 1591-1601. [CrossRef]

54. Yang, D.; Sun, C.; Zhang, J.; Lin, S.; Zhao, L.; Wang, L.; Lin, R.; Lv, J.; Xin, S. Proliferation of vascular smooth muscle cells under inflammation is regulated by NF-kB p65/microRNA-17/RB pathway activation. Int. J. Mol. Med. 2018, 41, 43-50. [CrossRef] [PubMed]

55. Sumagin, R.; Sarelius, I.H. Emerging understanding of roles for arterioles in inflammation. Microcirculation 2013, 20, 679-692. [CrossRef]

56. Granger, D.N.; Rodrigues, S.F.; Yildirim, A.; Senchenkova, E.Y. Microvascular responses to cardiovascular risk factors. Microcirculation 2010, 17, 192-205. [CrossRef]

57. Stokes, K.Y.; Granger, D.N. The microcirculation: A motor for the systemic inflammatory response and large vessel disease induced by hypercholesterolaemia? J. Physiol. 2005, 562, 647-653. [CrossRef]

58. Nellore, K.; Harris, N.R. L-arginine and antineutrophil serum enable venular control of capillary perfusion in hypercholesterolemic rats. Microcirculation 2002, 9, 477-485. [CrossRef]

59. Nishimura, S.; Manabe, I.; Nagasaki, M.; Seo, K.; Yamashita, H.; Hosoya, Y.; Ohsugi, M.; Tobe, K.; Kadowaki, T.; Nagai, R.; et al. In vivo imaging in mice reveals local cell dynamics and inflammation in obese adipose tissue. J. Clin. Investig. 2008, 118, 710-721. [CrossRef]

60. Nishimura, S.; Manabe, I.; Nagasaki, M.; Hosoya, Y.; Yamashita, H.; Fujita, H.; Ohsugi, M.; Tobe, K.; Kadowaki, T.; Nagai, R.; et al. Adipogenesis in obesity requires close interplay between differentiating adipocytes, stromal cells, and blood vessels. Diabetes 2007, 56, 1517-1526. [CrossRef]

61. Manlove, F.R. Retinal and choroidal arterioles in malignant hypertension; a clinical and pathologic study of 15 cases. Arch. Intern. Med. 1946, 78, 419-440. [CrossRef]

62. Feihl, F.; Liaudet, L.; Waeber, B.; Levy, B.I. Hypertension: A disease of the microcirculation? Hypertension 2006, 48, 1012-1017. [CrossRef] [PubMed]

63. Dehaini, H.; Fardoun, M.; Abou-Saleh, H.; El-Yazbi, A.; Eid, A.A.; Eid, A.H. Estrogen in vascular smooth muscle cells: A friend or a foe? Vasc. Pharmacol. 2018, 111, 15-21. [CrossRef] [PubMed]

64. Bennett, M.R.; Sinha, S.; Owens, G.K. Vascular smooth muscle cells in atherosclerosis. Circ. Res. 2016, 118, 692-702. [CrossRef] [PubMed]

65. Rudijanto, A. The role of vascular smooth muscle cells on the pathogenesis of atherosclerosis. Acta Med. Indones 2007, 39, 86-93.

66. Baldin, V.; Lukas, J.; Marcote, M.J.; Pagano, M.; Draetta, G. Cyclin D1 is a nuclear protein required for cell cycle progression in G1. Genes Dev. 1993, 7, 812-821. [CrossRef] 
67. Fu, M.; Wang, C.; Li, Z.; Sakamaki, T.; Pestell, R.G. Minireview: Cyclin D1: Normal and abnormal functions. Endocrinology 2004, 145, 5439-5447. [CrossRef]

68. Sherr, C.J. G1 phase progression: Cycling on cue. Cell 1994, 79, 551-555. [CrossRef]

69. Guo, J.; Li, L.; Wu, Y.J.; Yan, Y.; Xu, X.N.; Wang, S.B.; Yuan, T.Y.; Fang, L.H.; Du, G.H. Inhibitory effects of Brazilin on the vascular smooth muscle cell proliferation and migration induced by PDGF-BB. Am. J. Chin. Med. 2013, 41, 1283-1296. [CrossRef]

70. Song, J.H.; Jeong, G.H.; Park, S.L.; Won, S.Y.; Paek, N.S.; Lee, B.H.; Moon, S.K. Inhibitory effects of fermented extract of Ophiopogon japonicas on thrombin-induced vascular smooth muscle cells. Mol. Med. Rep. 2016, 13, 426-432. [CrossRef]

71. Marra, D.E.; Simoncini, T.; Liao, J.K. Inhibition of vascular smooth muscle cell proliferation by sodium salicylate mediated by upregulation of p21(Waf1) and p27(Kip1). Circulation 2000, 102, 2124-2130. [CrossRef]

72. Mebratu, Y.; Tesfaigzi, Y. How ERK1/2 activation controls cell proliferation and cell death: Is subcellular localization the answer? Cell Cycle 2009, 8, 1168-1175. [CrossRef] [PubMed]

73. Pyles, J.M.; March, K.L.; Franklin, M.; Mehdi, K.; Wilensky, R.L.; Adam, L.P. Activation of MAP kinase in vivo follows balloon overstretch injury of porcine coronary and carotid arteries. Circ. Res. 1997, 81, 904-910. [CrossRef] [PubMed]

74. Dubey, R.K.; Roy, A.; Overbeck, H.W. Culture of renal arteriolar smooth muscle cells. Mitogenic responses to angiotensin II. Circ. Res. 1992, 71, 1143-1152. [CrossRef] [PubMed]

75. Abberton, K.M.; Taylor, N.H.; Healy, D.L.; Rogers, P.A. Vascular smooth muscle cell proliferation in arterioles of the human endometrium. Hum. Reprod. 1999, 14, 1072-1079. [CrossRef]

76. El-Beblawy, N.M.; Andrawes, N.G.; Ismail, E.A.; Enany, B.E.; El-Seoud, H.S.; Erfan, M.A. Serum and urinary orosomucoid in young patients with type 1 diabetes: A link between inflammation, microvascular complications, and subclinical atherosclerosis. Clin. Appl. Thromb. Hemost. 2016, 22, 718-726. [CrossRef]

77. Gibbons, G.H.; Dzau, V.J. The emerging concept of vascular remodeling. N. Engl. J. Med. 1994, 330, 1431-1438. [CrossRef]

78. Ruiz, E.; Gordillo-Moscoso, A.; Padilla, E.; Redondo, S.; Rodriguez, E.; Reguillo, F.; Briones, A.M.; van Breemen, C.; Okon, E.; Tejerina, T. Human vascular smooth muscle cells from diabetic patients are resistant to induced apoptosis due to high Bcl-2 expression. Diabetes 2006, 55, 1243-1251. [CrossRef]

79. Ruiz, E.; Redondo, S.; Gordillo-Moscoso, A.; Tejerina, T. Pioglitazone induces apoptosis in human vascular smooth muscle cells from diabetic patients involving the transforming growth factor- $\beta /$ activin receptor-like kinase-4/5/7/Smad2 signaling pathway. J. Pharmacol. Exp. Ther. 2007, 321, 431-438. [CrossRef]

80. Bottone, M.G.; Santin, G.; Aredia, F.; Bernocchi, G.; Pellicciari, C.; Scovassi, A.I. Morphological features of organelles during apoptosis: An overview. Cells 2013, 2, 294-305. [CrossRef]

81. Sheikh, A.Q.; Lighthouse, J.K.; Greif, D.M. Recapitulation of developing artery muscularization in pulmonary hypertension. Cell Rep. 2014, 6, 809-817. [CrossRef]

82. Voelkel, N.F.; Gomez-Arroyo, J.; Mizuno, S. COPD/emphysema: The vascular story. Pulm. Circ. 2011, 1, 320-326. [CrossRef] [PubMed]

83. Louis, S.F.; Zahradka, P. Vascular smooth muscle cell motility: From migration to invasion. Exp. Clin. Cardiol. 2010, 15, e75-e85. [PubMed]

84. Chang, S.; Song, S.; Lee, J.; Yoon, J.; Park, J.; Choi, S.; Park, J.K.; Choi, K.; Choi, C. Phenotypic modulation of primary vascular smooth muscle cells by short-term culture on micropatterned substrate. PLoS One 2014, 9, e88089. [CrossRef] [PubMed]

85. Motawea, H.K.; Jeyaraj, S.C.; Eid, A.H.; Mitra, S.; Unger, N.T.; Ahmed, A.A.; Flavahan, N.A.; Chotani, M.A. Cyclic AMP-Rap1A signaling mediates cell surface translocation of microvascular smooth muscle $\alpha 2 \mathrm{C}$-adrenoceptors through the actin-binding protein filamin-2. Am. J. Physiol. Cell Physiol. 2013, 305, C829-C845. [CrossRef] [PubMed]

86. DeMali, K.A.; Wennerberg, K.; Burridge, K. Integrin signaling to the actin cytoskeleton. Curr. Opin. Cell Biol. 2003, 15, 572-582. [CrossRef]

87. Schmidt, C.E.; Horwitz, A.F.; Lauffenburger, D.A.; Sheetz, M.P. Integrin-cytoskeletal interactions in migrating fibroblasts are dynamic, asymmetric, and regulated. J. Cell Biol. 1993, 123, 977-991. [CrossRef]

88. Sokolova, A.; Hill, M.D.; Rahimi, F.; Warden, L.A.; Halliday, G.M.; Shepherd, C.E. Monocyte chemoattractant protein-1 plays a dominant role in the chronic inflammation observed in Alzheimer's disease. Brain Pathol. 2009, 19, 392-398. [CrossRef] 
89. Herbin, O.; Regelmann, A.G.; Ramkhelawon, B.; Weinstein, E.G.; Moore, K.J.; Alexandropoulos, K. Monocyte adhesion and plaque recruitment during atherosclerosis development is regulated by the adapter protein Chat-H/SHEP1. Arterioscler. Thromb. Vasc. Biol. 2016, 36, 1791-1801. [CrossRef]

90. Gwon, W.G.; Joung, E.J.; Kwon, M.S.; Lim, S.J.; Utsuki, T.; Kim, H.R. Sargachromenol protects against vascular inflammation by preventing TNF- $\alpha$-induced monocyte adhesion to primary endothelial cells via inhibition of NF-KB activation. Int. Immunopharmacol. 2017, 42, 81-89. [CrossRef]

91. Granger, D.N.; Kubes, P. The microcirculation and inflammation: Modulation of leukocyte-endothelial cell adhesion. J. Leukoc. Biol. 1994, 55, 662-675. [CrossRef]

92. Bruce, A.C.; Kelly-Goss, M.R.; Heuslein, J.L.; Meisner, J.K.; Price, R.J.; Peirce, S.M. Monocytes are recruited from venules during arteriogenesis in the murine spinotrapezius ligation model. Arterioscler. Thromb. Vasc. Biol. 2014, 34, 2012-2022. [CrossRef] [PubMed]

93. Alvarez, A.; Cerda-Nicolas, M.; Naim Abu Nabah, Y.; Mata, M.; Issekutz, A.C.; Panes, J.; Lobb, R.R.; Sanz, M.J. Direct evidence of leukocyte adhesion in arterioles by angiotensin II. Blood 2004, 104, 402-408. [CrossRef] [PubMed]

94. Boneh, A.; Mandla, S.; Tenenhouse, H.S. Phorbol myristate acetate activates protein kinase C, stimulates the phosphorylation of endogenous proteins and inhibits phosphate transport in mouse renal tubules. Biochim. Biophys. Acta 1989, 1012, 308-316. [CrossRef]

95. Gamet-Payrastre, L.; Manenti, S.; Gratacap, M.P.; Tulliez, J.; Chap, H.; Payrastre, B. Flavonoids and the inhibition of PKC and PI 3-kinase. Gen. Pharmacol. 1999, 32, 279-286. [CrossRef]

96. Opitz, F.; Schenke-Layland, K.; Cohnert, T.U.; Stock, U.A. Phenotypical plasticity of vascular smooth muscle cells-effect of in vitro and in vivo shear stress for tissue engineering of blood vessels. Tissue Eng. 2007, 13, 2505-2514. [CrossRef]

97. Bacakova, L.; Travnickova, M.; Filova, E.; Matějka, R.; Stepanovska, J.; Musilkova, J.; Zarubova, J.; Molitor, M. The role of vascular smooth muscle cells in the physiology and pathophysiology of blood vessels. Muscle Cell Tissue Curr. Status Res. Field 2018, 229. [CrossRef]

98. Rzucidlo, E.M.; Martin, K.A.; Powell, R.J. Regulation of vascular smooth muscle cell differentiation. J. Vasc. Surg. 2007, 45 (Suppl. A), A25-A32. [CrossRef]

99. Jiang, H.; Lun, Y.; Wu, X.; Xia, Q.; Zhang, X.; Xin, S.; Zhang, J. Association between the hypomethylation of osteopontin and integrin $\beta 3$ promoters and vascular smooth muscle cell phenotype switching in great saphenous varicose veins. Int. J. Mol. Sci. 2014, 15, 18747-18761. [CrossRef]

100. Chistiakov, D.A.; Orekhov, A.N.; Bobryshev, Y.V. Vascular smooth muscle cell in atherosclerosis. Acta Physiol. (Oxf.) 2015, 214, 33-50. [CrossRef]

101. Wang, D.; Chang, P.S.; Wang, Z.; Sutherland, L.; Richardson, J.A.; Small, E.; Krieg, P.A.; Olson, E.N. Activation of cardiac gene expression by myocardin, a transcriptional cofactor for serum response factor. Cell 2001, 105, 851-862. [CrossRef]

102. Chen, J.; Kitchen, C.M.; Streb, J.W.; Miano, J.M. Myocardin: A component of a molecular switch for smooth muscle differentiation. J. Mol. Cell. Cardiol. 2002, 34, 1345-1356. [CrossRef] [PubMed]

103. Du, K.L.; Ip, H.S.; Li, J.; Chen, M.; Dandre, F.; Yu, W.; Lu, M.M.; Owens, G.K.; Parmacek, M.S. Myocardin is a critical serum response factor cofactor in the transcriptional program regulating smooth muscle cell differentiation. Mol. Cell. Biol. 2003, 23, 2425-2437. [CrossRef] [PubMed]

104. Wang, Z.; Wang, D.Z.; Pipes, G.C.; Olson, E.N. Myocardin is a master regulator of smooth muscle gene expression. Proc. Natl. Acad. Sci. USA 2003, 100, 7129-7134. [CrossRef]

105. Owens, G.K.; Kumar, M.S.; Wamhoff, B.R. Molecular regulation of vascular smooth muscle cell differentiation in development and disease. Physiol. Rev. 2004, 84, 767-801. [CrossRef] [PubMed]

106. Yoshida, T.; Kawai-Kowase, K.; Owens, G.K. Forced expression of myocardin is not sufficient for induction of smooth muscle differentiation in multipotential embryonic cells. Arterioscler. Thromb. Vasc. Biol. 2004, 24, 1596-1601. [CrossRef] [PubMed]

107. Wang, Z.; Wang, D.Z.; Hockemeyer, D.; McAnally, J.; Nordheim, A.; Olson, E.N. Myocardin and ternary complex factors compete for SRF to control smooth muscle gene expression. Nature 2004, 428, 185-189. [CrossRef]

108. Taurin, S.; Sandbo, N.; Yau, D.M.; Sethakorn, N.; Kach, J.; Dulin, N.O. Phosphorylation of myocardin by extracellular signal-regulated kinase. J. Biol. Chem. 2009, 284, 33789-33794. [CrossRef]

109. Liao, X.H.; Wang, N.; Zhao, D.W.; Zheng, D.L.; Zheng, L.; Xing, W.J.; Ma, W.J.; Bao, L.Y.; Dong, J.; Zhang, T.C. STAT3 protein regulates vascular smooth muscle cell phenotypic switch by interaction with myocardin. J. Biol. Chem. 2015, 290, 19641-19652. [CrossRef] 
110. Xie, C.; Guo, Y.; Zhu, T.; Zhang, J.; Ma, P.X.; Chen, Y.E. Yap1 protein regulates vascular smooth muscle cell phenotypic switch by interaction with myocardin. J. Biol. Chem. 2012, 287, 14598-14605. [CrossRef]

111. Tang, R.H.; Zheng, X.L.; Callis, T.E.; Stansfield, W.E.; He, J.; Baldwin, A.S.; Wang, D.Z.; Selzman, C.H. Myocardin inhibits cellular proliferation by inhibiting NF-kB(p65)-dependent cell cycle progression. Proc. Natl. Acad. Sci. USA 2008, 105, 3362-3367. [CrossRef]

112. Denhardt, D.T.; Noda, M.; O’Regan, A.W.; Pavlin, D.; Berman, J.S. Osteopontin as a means to cope with environmental insults: Regulation of inflammation, tissue remodeling, and cell survival. J. Clin. Investig. 2001, 107, 1055-1061. [CrossRef] [PubMed]

113. O’Brien, E.R.; Garvin, M.R.; Stewart, D.K.; Hinohara, T.; Simpson, J.B.; Schwartz, S.M.; Giachelli, C.M. Osteopontin is synthesized by macrophage, smooth muscle, and endothelial cells in primary and restenotic human coronary atherosclerotic plaques. Arterioscler. Thromb. 1994, 14, 1648-1656. [CrossRef] [PubMed]

114. Zhao, M.; Xu, H.; Liang, F.; He, J.; Zhang, J. Association of osteopontin expression with the prognosis of glioma patient: A meta-analysis. Tumour. Biol. 2015, 36, 429-436. [CrossRef] [PubMed]

115. Mohamadpour, A.H.; Abdolrahmani, L.; Mirzaei, H.; Sahebkar, A.; Moohebati, M.; Ghorbani, M.; Ferns, G.A.; Ghayour-Mobarhan, M. Serum osteopontin concentrations in relation to coronary artery disease. Arch. Med. Res. 2015, 46, 112-117. [CrossRef] [PubMed]

116. Parrish, A.R.; Ramos, K.S. Differential processing of osteopontin characterizes the proliferative vascular smooth muscle cell phenotype induced by allylamine. J. Cell. Biochem. 1997, 65, 267-275. [CrossRef]

117. Liaw, L.; Skinner, M.P.; Raines, E.W.; Ross, R.; Cheresh, D.A.; Schwartz, S.M.; Giachelli, C.M. The adhesive and migratory effects of osteopontin are mediated via distinct cell surface integrins. Role of alpha v beta 3 in smooth muscle cell migration to osteopontin in vitro. J. Clin. Investig. 1995, 95, 713-724. [CrossRef]

118. Li, J.J.; Han, M.; Wen, J.K.; Li, A.Y. Osteopontin stimulates vascular smooth muscle cell migration by inducing FAK phosphorylation and ILK dephosphorylation. Biochem. Biophys. Res. Commun. 2007, 356, 13-19. [CrossRef]

119. Gao, H.; Steffen, M.C.; Ramos, K.S. Osteopontin regulates $\alpha$-smooth muscle actin and calponin in vascular smooth muscle cells. Cell Biol. Int. 2012, 36, 155-161. [CrossRef]

120. Williams, E.S.; Wilson, E.; Ramos, K.S. NF-kappaB and matrix-dependent regulation of osteopontin promoter activity in allylamine-activated vascular smooth muscle cells. Oxid. Med. Cell. Longev. 2012, 2012, 496540. [CrossRef]

121. Adams, C.C.; Workman, J.L. Binding of disparate transcriptional activators to nucleosomal DNA is inherently cooperative. Mol. Cell. Biol. 1995, 15, 1405-1421. [CrossRef]

122. Shanahan, C.M.; Weissberg, P.L.; Metcalfe, J.C. Isolation of gene markers of differentiated and proliferating vascular smooth muscle cells. Circ. Res. 1993, 73, 193-204. [CrossRef] [PubMed]

123. Kee, H.J.; Kim, G.R.; Cho, S.N.; Kwon, J.S.; Ahn, Y.; Kook, H.; Jeong, M.H. miR-18a-5p MicroRNA increases vascular smooth muscle cell differentiation by downregulating syndecan4. Korean Circ. J. 2014, 44, 255-263. [CrossRef] [PubMed]

124. Bockmeyer, C.L.; Kern, D.S.; Forstmeier, V.; Lovric, S.; Modde, F.; Agustian, P.A.; Steffens, S.; Birschmann, I.; Traeder, J.; Dammrich, M.E.; et al. Arteriolar vascular smooth muscle cell differentiation in benign nephrosclerosis. Nephrol. Dial. Transpl. 2012, 27, 3493-3501. [CrossRef] [PubMed]

125. Lin, C.M.; Wang, B.W.; Pan, C.M.; Fang, W.J.; Chua, S.K.; Hou, S.W.; Chang, H.; Shyu, K.G. Effects of flavonoids on MicroRNA 145 regulation through Klf4 and myocardin in neointimal formation in vitro and in vivo. J. Nutr. Biochem. 2018, 52, 27-35. [CrossRef] [PubMed]

126. Lawrence, T. The nuclear factor NF-кB pathway in inflammation. Cold Spring Harb. Perspect. Biol. 2009, 1, a001651. [CrossRef] [PubMed]

127. Mehrhof, F.B.; Schmidt-Ullrich, R.; Dietz, R.; Scheidereit, C. Regulation of vascular smooth muscle cell proliferation: Role of NF-кB revisited. Circ. Res. 2005, 96, 958-964. [CrossRef]

128. Brasier, A.R. The nuclear factor- $\mathrm{kB}$-interleukin-6 signalling pathway mediating vascular inflammation. Cardiovasc. Res. 2010, 86, 211-218. [CrossRef]

129. Pamukcu, B.; Lip, G.Y.; Shantsila, E. The nuclear factor-Kappa B pathway in atherosclerosis: A potential therapeutic target for atherothrombotic vascular disease. Thromb. Res. 2011, 128, 117-123. [CrossRef]

130. Pateras, I.; Giaginis, C.; Tsigris, C.; Patsouris, E.; Theocharis, S. NF-kB signaling at the crossroads of inflammation and atherogenesis: Searching for new therapeutic links. Expert Opin. Ther. Targets 2014, 18, 1089-1101. [CrossRef]

131. Dickson, K.M.; Bhakar, A.L.; Barker, P.A. TRAF6-dependent NF-kB transcriptional activity during mouse development. Dev. Dyn. Off. Publ. Am. Assoc. Anat. 2004, 231, 122-127. [CrossRef] 
132. Liu, H.; Wang, L.; Ma, H.; Guo, R.; Kang, R.; Han, J.; Dong, Z. Coumestrol inhibits carotid sinus baroreceptor activity by cAMP/PKA dependent nitric oxide release in anesthetized male rats. Biochem. Pharmacol. 2015, 93, 42-48. [CrossRef] [PubMed]

133. Diaz-Gerevini, G.T.; Repossi, G.; Dain, A.; Tarres, M.C.; Das, U.N.; Eynard, A.R. Beneficial action of resveratrol: How and why? Nutrition 2016, 32, 174-178. [CrossRef] [PubMed]

134. Chotani, M.A.; Mitra, S.; Eid, A.H.; Han, S.A.; Flavahan, N.A. Distinct cAMP signaling pathways differentially regulate $\alpha 2 \mathrm{C}$-adrenoceptor expression: Role in serum induction in human arteriolar smooth muscle cells. Am. J. Physiol. Heart Circ. Physiol. 2005, 288, H69-H76. [CrossRef] [PubMed]

135. Klingenberg, R.; Hansson, G.K. Treating inflammation in atherosclerotic cardiovascular disease: Emerging therapies. Eur. Heart J. 2009, 30, 2838-2844. [CrossRef] [PubMed]

136. Yee, K.L.; Weaver, V.M.; Hammer, D.A. Integrin-mediated signalling through the MAP-kinase pathway. IET Syst. Biol. 2008, 2, 8-15. [CrossRef] [PubMed]

137. Tian, H.; Ketova, T.; Hardy, D.; Xu, X.; Gao, X.; Zijlstra, A.; Blobe, G.C. Endoglin mediates vascular maturation by promoting vascular smooth muscle cell migration and spreading. Arterioscler. Thromb. Vasc. Biol. 2017, 37, 1115-1126. [CrossRef] [PubMed]

138. Dong, L.H.; Wen, J.K.; Liu, G.; McNutt, M.A.; Miao, S.B.; Gao, R.; Zheng, B.; Zhang, H.; Han, M. Blockade of the Ras-extracellular signal-regulated kinase $1 / 2$ pathway is involved in smooth muscle $22 \alpha$-mediated suppression of vascular smooth muscle cell proliferation and neointima hyperplasia. Arterioscler. Thromb. Vasc. Biol. 2010, 30, 683-691. [CrossRef]

139. Hong, H.; McCullough, C.M.; Stegemann, J.P. The role of ERK signaling in protein hydrogel remodeling by vascular smooth muscle cells. Biomaterials 2007, 28, 3824-3833. [CrossRef]

140. Li, R.C.; Cindrova-Davies, T.; Skepper, J.N.; Sellers, L.A. Prostacyclin induces apoptosis of vascular smooth muscle cells by a cAMP-mediated inhibition of extracellular signal-regulated kinase activity and can counteract the mitogenic activity of endothelin-1 or basic fibroblast growth factor. Circ. Res. 2004, 94, 759-767. [CrossRef]

141. Pan, Q.; Liu, H.; Zheng, C.; Zhao, Y.; Liao, X.; Wang, Y.; Chen, Y.; Zhao, B.; Lazartigues, E.; Yang, Y.; et al. Microvesicles derived from inflammation-challenged endothelial cells modulate vascular smooth muscle cell functions. Front. Physiol. 2017, 7, 692. [CrossRef]

142. Lee, S.J.; Baek, S.E.; Jang, M.A.; Kim, C.D. Osteopontin plays a key role in vascular smooth muscle cell proliferation via EGFR-mediated activation of AP-1 and C/EBP $\beta$ pathways. Pharmacol. Res. 2016, 108, 1-8. [CrossRef] [PubMed]

143. Toyoshima, H.; Hunter, T. p27, a novel inhibitor of G1 cyclin-CDK protein kinase activity, is related to p21. Cell 1994, 78, 67-74. [CrossRef]

144. Xiong, Y.; Hannon, G.J.; Zhang, H.; Casso, D.; Kobayashi, R.; Beach, D. p21 is a universal inhibitor of cyclin kinases. Nature 1993, 366, 701-704. [CrossRef] [PubMed]

145. Zhong, Y.; Yu, W.; Feng, J.; Fan, Z.; Li, J. Curcumin suppresses tumor necrosis factor-alpha-induced matrix metalloproteinase-2 expression and activity in rat vascular smooth muscle cells via the NF- $\mathrm{B}$ pathway. Exp. Ther. Med. 2014, 7, 1653-1658. [CrossRef]

146. Moon, S.K.; Cho, G.O.; Jung, S.Y.; Gal, S.W.; Kwon, T.K.; Lee, Y.C.; Madamanchi, N.R.; Kim, C.H. Quercetin exerts multiple inhibitory effects on vascular smooth muscle cells: Role of ERK1/2, cell-cycle regulation, and matrix metalloproteinase-9. Biochem. Biophys. Res. Commun. 2003, 301, 1069-1078. [CrossRef]

147. Moon, S.K.; Cha, B.Y.; Kim, C.H. ERK1/2 mediates TNF- $\alpha$-induced matrix metalloproteinase- 9 expression in human vascular smooth muscle cells via the regulation of NF- $\mathrm{KB}$ and AP-1: Involvement of the ras dependent pathway. J. Cell. Physiol. 2004, 198, 417-427. [CrossRef]

148. Chung, C.H.; Lin, K.T.; Chang, C.H.; Peng, H.C.; Huang, T.F. The integrin $\alpha 2 \beta 1$ agonist, aggretin, promotes proliferation and migration of VSMC through NF- $\mathrm{BB}$ translocation and PDGF production. Br. J. Pharmacol. 2009, 156, 846-856. [CrossRef]

149. Guo, R.; Li, W.; Liu, B.; Li, S.; Zhang, B.; Xu, Y. Resveratrol protects vascular smooth muscle cells against high glucose-induced oxidative stress and cell proliferation in vitro. Med. Sci. Monit. Basic Res. 2014, 20, 82-92. [CrossRef]

(C) 2019 by the authors. Licensee MDPI, Basel, Switzerland. This article is an open access article distributed under the terms and conditions of the Creative Commons Attribution (CC BY) license (http://creativecommons.org/licenses/by/4.0/). 